\title{
Primary and secondary organic winter aerosols in Mediterranean cities under different mixing layer conditions (Barcelona and Granada)
}

\author{
Barend L. van Drooge ${ }^{1}$ (D) $\cdot$ Roger Garatachea ${ }^{1} \cdot$ Cristina Reche $^{1} \cdot$ Gloria Titos $^{2,3} \cdot$ Andres Alastuey $^{1}$. \\ Hassan Lyamani ${ }^{2,3} \cdot$ Lucas Alados-Arboledas $^{2,3} \cdot$ Xavier Querol $^{1} \cdot$ Joan O. Grimalt ${ }^{1}$
}

Received: 4 June 2021 / Accepted: 1 September 2021

(C) The Author(s), under exclusive licence to Springer-Verlag GmbH Germany, part of Springer Nature 2021

\begin{abstract}
$\mathrm{PM}_{10}$ was collected during an EMEP winter campaign of 2017-2018 in two urban background sites in Barcelona (BCN) and Granada (GRA), two Mediterranean cities in the coast and inland, respectively. The concentrations of $\mathrm{PM}_{10}$, organic carbon $(\mathrm{OC})$, elemental carbon (EC), and organic molecular tracer compounds such as hopanes, anhydro-saccharides, polycyclic aromatic hydrocarbon, and several biogenic and anthropogenic markers of secondary organic aerosols (SOA) were two times higher in GRA compared to BCN and related to the atmospheric mixing heights in the areas. Multivariate curve resolution (MCR-ALS) source apportionment analysis identified primary emissions sources (traffic + biomass burning) that were responsible for the $50 \%$ and $20 \%$ of the organic aerosol contributions in Granada and Barcelona, respectively. The contribution of biomass burning was higher in the holidays than in the working days in GRA while all primary combustion emissions decreased in holidays in BCN. The MCR-ALS identified that oxidative species and SOA formation processes contributed to $40 \%$ and $80 \%$ in Granada and Barcelona, respectively. Aged SOA was dominant in Granada and Barcelona under stagnant atmospheric conditions and in presence of air pollution. On the other hand, fresh SOA contributions from $\alpha$-pinene oxidation (cis-pinonic acid) were three times higher in Barcelona than Granada and could be related to new particle formation, essentially due to overall cleaner air conditions and elevated air temperatures.
\end{abstract}

Keywords Urban air quality $\cdot$ PM $\cdot$ Organic aerosol $\cdot$ PAH $\cdot$ SOA $\cdot$ Source apportionment

Highlights

- Wintertime concentrations of air pollution indicators are higher in Granada than Barcelona.

- Atmospheric mixing layer height is lower in Granada than Barcelona.

- Lower mixing height promotes accumulation of aged secondary aerosol.

- Clean air conditions in urban areas promote fresh secondary aerosol formation.

Responsible Editor: Gerhard Lammel

Barend L. van Drooge

barend.vandrooge@idaea.csic.es

1 Institute of Environmental Assessment and Water Research (IDÆA-CSIC), 08034 Barcelona, Spain

2 Andalusian Institute of Earth System Research (IISTA-CEAMA), University of Granada, Junta de Andalucía, 18006 Granada, Spain

3 Department of Applied Physics, University of Granada, 18071 Granada, Spain

\section{Introduction}

Atmospheric particulate matter (PM) is deleterious for human health (Burnett et al. 2014; Cohen et al. 2017). In urban areas, PM is constituted by complex mixtures originating from different sources, including secondary aerosol formation from biogenic and anthropogenic origin (Bi et al. 2008; Brines et al. 2019; Pöschl 2005; Schauer et al. 2007). The atmospheric conditions also play an important role on the ambient PM concentrations. Precipitation and strong winds remove and disperse pollutants, while stagnant calm weather conditions lead to contaminant accumulation from primary emissions (Vardoulakis and Kassomenos 2008; Lyamani et al. 2012), which is further accentuated by lower mixing layer heights (MHs) (Guzman-Torres et al. 2009; Lageron and Staquet 2016; Vecchi et al. 2007; van Drooge et al. 2012).

A significant, but variable fraction of the PM consists of organic material, between 20 and $90 \%$ of the aerosol mass 
(Kanakidou et al. 2005), which can originate from primary and secondary processes (Donahue et al. 2009). Primary organic aerosols (POA) are directly emitted into the atmosphere from their source, which can be vehicle exhausts, biomass burning, cooking activities, industry emissions, and soil and road dust resuspension (Brines et al. 2019; Pöschl 2005; Schauer et al. 2007). In the presence of atmospheric oxidants, such as $\mathrm{NO}_{\mathrm{x}}, \mathrm{O}_{3}$, and $\mathrm{OH}$ radicals, these primary organic compounds can be transformed into more oxygenated products with different physical-chemical properties (Donahue et al. 2009). The formation of secondary organic aerosols (SOA) takes place in the atmosphere after photochemical transformation of volatile organic compounds (VOCs) (Heald et al. 2010; Kleindienst et al. 2012; Paulot et al. 2011). These VOCs may originate from fossil fuels and biogenic sources, e.g., vegetation, that under photooxidation and adequate atmospheric physical conditions can generate new particles by nucleation, gas-particle partitioning (condensation), and heterogeneous or multiphase chemical reactions (Pöschl 2005). Oxygenated organic compounds, such as dicarboxylic acids, may be dominant SOA constituents in urban areas, and in the absence of biomass burning, they may constitute $40-90 \%$ of the total organic fraction in fine PM (Alier et al. 2013; Hallquist et al. 2009; Jimenez et al. 2009; van Drooge et al. 2018). However, the influence of the atmospheric vertical structure in the formation of these SOA components needs further clarification.

In the present study, the molecular organic composition of $\mathrm{PM}_{10}$ from two Mediterranean cities, Barcelona (BCN) and Granada (GRA) (Fig. 1), one with a coastal-marine climate and the other with a continental climate influenced by mountain breeze, is compared. These two cities are characterized by high solar radiation (even in winter), frequent occurrence of stagnant air conditions due to anticyclones on a synoptic scale, and distinct atmospheric MHs. BCN has higher MH than Granada, namely in winter. In both cities, high traffic density influences the urban air quality leading to relatively high PM and EC concentrations (Brines et al. 2019; Pey et al. 2010; Querol et al. 2008; Titos et al. 2017; van Drooge et al. 2018). These conditions may generate photochemical reaction products, leading to new particle formation and secondary aerosols (Brines et al. 2015, 2019; Lyamani et al. 2012; Perez et al. 2010; Triantafyllou 2001). However, there are still many uncertainties in the interaction between chemical components and meteorological conditions that have not been adequately mastered.

For the purpose of the present study, $40 \mathrm{PM}_{10}$ samples were collected urban background sites in $\mathrm{BCN}(n=17)$ and GRA $(n=23)$ and analyzed on organic molecular tracer compounds. The selected $\mathrm{PM}_{10}$ samples from wintertime allow an assessment of the similarities and differences in OA concentrations and source contributions in the two sites by using the data set of the molecular organic tracer compounds. These compounds only present a small fraction of the OA mass, but the relatively small number of tracer compounds can be used in chemometric methods for the apportionment of sources and processes to the OA. For this purpose, different techniques can be applied, such as chemical mass balance (CMB), principle component analysis (PCA), and positive matrix factorization (PMF). CMB uses emission source profiles of the compounds, which make it unable to identify unknown sources or processes. PCA uses orthogonal constraints, and the environmental interpretation of the results is not straightforward. PMF uses constraints that are more natural to interpret, such as non-negativity and uncertainty estimations in a non-linear distribution and source profile. Here, the multivariate curve resolution - alternating least square (MCR-ALS) method was applied (Tauler 1995). MCR-ALS uses alternating least square optimization under nonnegativity constraints that produces better source/process profiles than PCA and has shown to give results that are equivalent to PMF although it uses other algorithms (Tauler et al. 2006). The applied MCR-ALS methodology was successfully used in previous studies on organic tracer compounds in urban atmospheres (Alier et al. 2013; van Drooge et al. 2018).

The present paper is aimed to clarify some of these interactions between meteorology, air pollution, and particle formation.

\section{Materials and methods}

\section{$\mathrm{PM}_{10}$ sampling}

$\mathrm{BCN}$ is a densely populated city $\left(16,000\right.$ inhabitants $\left./ \mathrm{km}^{2}\right)$ situated in the northeast of the Iberian Peninsula along the coast of the Mediterranean Sea that determines its climate. A forested mountain range (Collserola, $510 \mathrm{~m}$ asl.) is situated northwest of the city, and river valleys (Llobregat and Besos), with industrial and agricultural activities, are situated in the south and north. Sampling was performed in an urban background site at $1.5 \mathrm{~m}$ above ground level in the garden of the IDAEA-CSIC research institute $\left(41^{\circ} 23.232^{\prime} \mathrm{N} ; 2^{\circ} 6.943^{\prime} \mathrm{E}\right.$; $100 \mathrm{~m}$ asl.; Fig. 1). The site has a quiet street at $20 \mathrm{~m}$ distance and a busy 6 lane avenue (70,000 vehicles/working day) at $200 \mathrm{~m}$ distance to the south.

GRA is a middle-large city (2600 inhabitants $\left./ \mathrm{km}^{2}\right)$, located in the southeast of the Iberian Peninsula at the foot of the Sierra Nevada mountains ( $3500 \mathrm{~m}$ asl.), with a continental Mediterranean climate. The city is surrounded by agricultural fields and some industries, especially in the south and west. Sampling was performed on the roof of the IISTA-CEAMA research institute $\left(37^{\circ} 9.840^{\prime} \mathrm{N} ; 3^{\circ} 36.301^{\prime} \mathrm{W} ; 680 \mathrm{~m}\right.$ asl.; Fig. 1) at $12 \mathrm{~m}$ above ground level. A highway and busy street are situated at $500 \mathrm{~m}$ and $200 \mathrm{~m}$ distance from this site, respectively. 


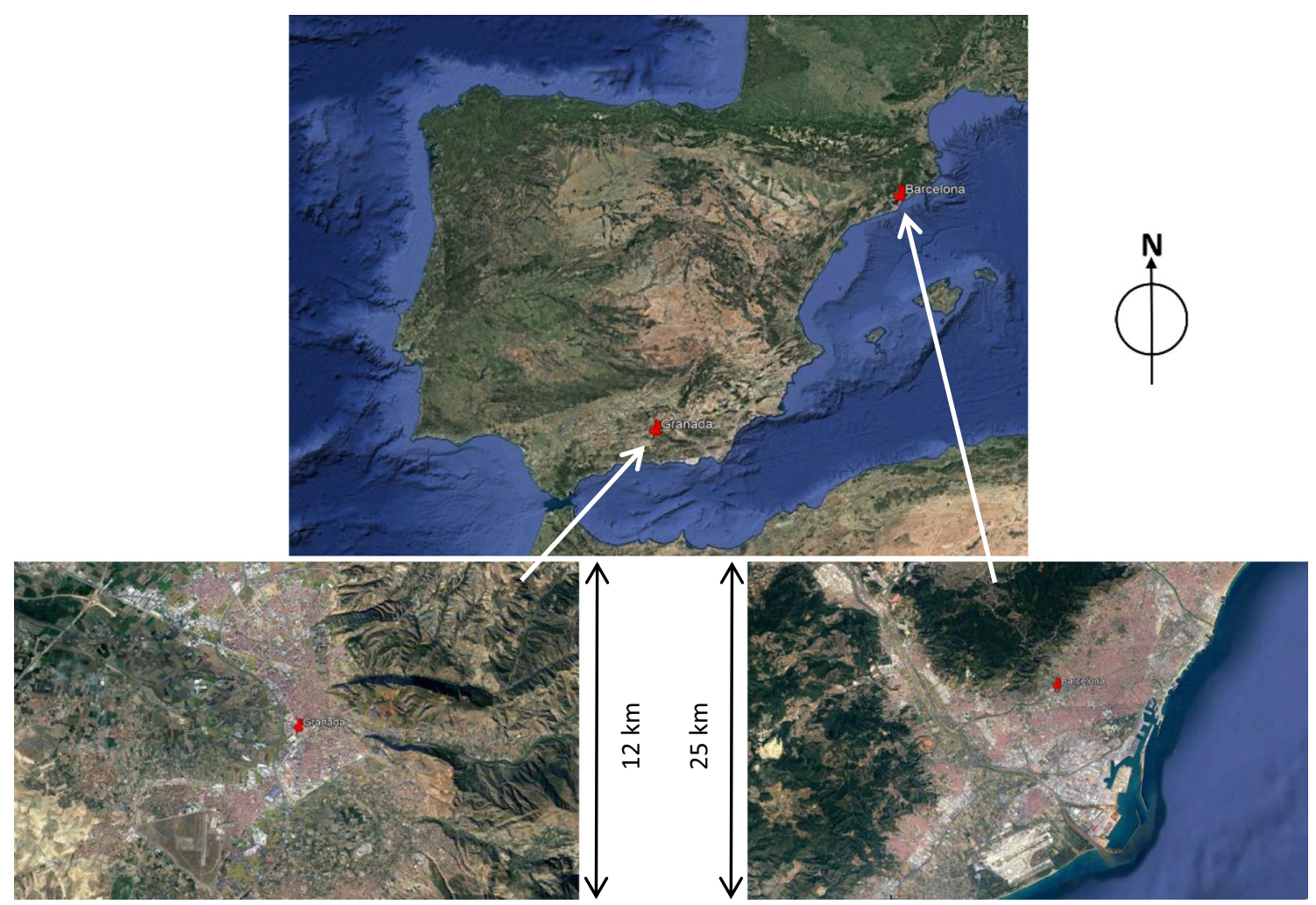

Fig. 1 Map of the location of sampling sites (red dots) in Barcelona (BCN) and Granada (GRA) on the Iberian Peninsula

Atmospheric particles with an aerodynamic diameter of less than $10 \mu \mathrm{m}\left(\mathrm{PM}_{10}\right)$ were sampled $(\mathrm{n}=40)$ within the framework of the EMEP campaign during winter 20172018 every 4th day. This sampling included working days $\left(n_{\mathrm{BCN}}=9 ; n_{\mathrm{GRA}}=13\right)$ and holidays $\left(n_{\mathrm{BCN}}=8 ; n_{\mathrm{GRA}}=10\right.$; including weekends and Christmas holidays). $\mathrm{PM}_{10}$ was collected on $150-\mathrm{mm}$-diameter microfiber quartz filters (2500QAT-UP, Pallflex, Pall Corporate) for periods of $24 \mathrm{~h}$ (starting at $7 \mathrm{~h}$ and $0 \mathrm{~h}$ UTC, in GRA and BCN, respectively) using a Digitel-DH80 HiVol-sampler (Digitel Elektronic AG, Switzerland) and CAV-A/MSb (MCV SA, Spain) at a flow rate of $30 \mathrm{~m}^{3} / \mathrm{h}$. After sampling, the filters were stored at -20 ${ }^{\circ} \mathrm{C}$ until analysis.

\section{Analytical procedure}

The $\mathrm{PM}_{10}$ filters were gravimetrically weighted after stabilized conditions, and OC and EC were determined in the samples by thermo-optical methods using the EUSAAR 2 protocol (Cavalli et al. 2010) (Table 1).

The organic molecular tracer compounds were determined in a quarter part of the $\mathrm{PM}_{10}$ filter by a solvent extraction method that is described in detail elsewhere (Alier et al. 2013; Fontal et al. 2015; van Drooge et al. 2018). Briefly, the filter fraction was spiked with surrogate standards and ultrasonically extracted ( 3 times) in a $10-\mathrm{mL}$ mixture of methanol and dichloromethane (1:2 v/v), filtered, and concentrated to $1 \mathrm{~mL}$. A $25-\mu \mathrm{L}$ aliquot was used for the analysis of polar compounds, after derivatization to form trimethylsilyl ethers (alcohols) or esters (acids). The remaining extract was dissolved with n-hexane and analyzed for non-polar compounds, i.e., polycyclic aromatic hydrocarbons (PAHs) and hopanes. The extracts were injected into a gas chromatograph (GC) coupled to a mass spectrometer (MS) (Thermo Trace GC Ultra - DSQ II) that was equipped with a 60-m fused capillary column $\left(\mathrm{RXi}{ }^{\circledR} 5 \mathrm{Si}\right.$ MS $0.25 \mathrm{~mm} \times 0.25 \mu \mathrm{m}$ film thickness). Electron impact ionization $(70 \mathrm{eV})$ was used, and the MS was operated in full-scan mode.

The organic compounds were identified by their chromatographic retention times and their $\mathrm{m} / \mathrm{z}$ fragments (Table 2). The internal standard method was used to quantify compounds using the surrogate standards in the samples. The recoveries of the surrogate standards were higher than $70 \%$, and the field blank levels of the analyzed compounds were between 1 and $30 \%$ of the sample levels. The concentrations of the molecular tracer compounds were higher than the limits of quantification (LOQ). The LOQs were calculated by dividing the lowest measured levels in the standard calibration curves by the volumes of the analyzed sample fraction. The LOQs were $0.1 \mathrm{ng} / \mathrm{m}^{3}$ for the saccharides, $0.06 \mathrm{ng} / \mathrm{m}^{3}$ for the acids, and $0.005 \mathrm{ng} / \mathrm{m}^{3}$ for PAHs and hopanes. 
Table 1 Meteorological variables, mixing height, average concentration, standard deviation, working days/holidays ratio (WD/ $\mathrm{HD}$ ), and regional air mass/other air mass (REG/O) ratio of $\mathrm{PM}_{10}, \mathrm{OC}$, and EC that were measured in Barcelona (BCN) and Granada (GRA). $\mathrm{GRA} / \mathrm{BCN}$ indicates the ratios between average concentrations.

\begin{tabular}{|c|c|c|c|c|c|c|c|c|c|}
\hline & \multicolumn{4}{|l|}{$\mathrm{BCN}$} & \multicolumn{4}{|l|}{ GRA } & \multirow{2}{*}{$\begin{array}{l}\text { GRA/ } \\
\text { BCN }\end{array}$} \\
\hline & av. & sd. & $\begin{array}{l}\text { WD/ } \\
\mathrm{HD}\end{array}$ & $\begin{array}{l}\text { REG/ } \\
\mathrm{O}\end{array}$ & av. & sd. & $\begin{array}{l}\text { WD/ } \\
\mathrm{HD}\end{array}$ & $\begin{array}{l}\text { REG/ } \\
\mathrm{O}\end{array}$ & \\
\hline Mixing height (m agl) & 470 & 264 & 0.8 & 0.9 & 206 & 97 & 0.9 & 0.6 & \\
\hline Temperature $\left({ }^{\circ} \mathrm{C}\right)$ & 10 & 3 & 0.9 & 0.9 & 8 & 2 & 1.2 & 1.3 & \\
\hline Relative humidity (\%) & 65 & 13 & 1.1 & 1.3 & 61 & 12 & 0.9 & 0.9 & \\
\hline Wind speed $(\mathrm{m} / \mathrm{s})$ & 3 & 1 & 0.9 & 0.7 & 4 & 2 & 0.9 & 0.9 & \\
\hline $\operatorname{PM} 10\left(\mu \mathrm{g} / \mathrm{m}^{3}\right)$ & 12.5 & 4.2 & 1.4 & 1.4 & 28.5 & 11.8 & 1.2 & 1.5 & 2.3 \\
\hline $\mathrm{OC}\left(\mu \mathrm{g} / \mathrm{m}^{3}\right)$ & 2.5 & 1.1 & 1.2 & 1.6 & 5.7 & 2.9 & 1.2 & 1.5 & 2.3 \\
\hline $\mathrm{EC}\left(\mu \mathrm{g} / \mathrm{m}^{3}\right)$ & 1.1 & 0.6 & 2.3 & 2.2 & 2.1 & 1.3 & 1.7 & 1.8 & 1.9 \\
\hline
\end{tabular}

Table 2 Average concentration, standard deviation, working days/ holidays ratio (WD/HD), and regional air mass/other air mass (REG/O) ratio of the organic tracer compounds $\left(\mathrm{ng} / \mathrm{m}^{3}\right.$; abbreviation and GC-MS ion) that were measured in Barcelona (BCN) and Granada (GRA). GRA/ $\mathrm{BCN}$ indicates the ratios between average concentrations

\begin{tabular}{|c|c|c|c|c|c|c|c|c|c|}
\hline & \multicolumn{4}{|l|}{$\mathrm{BCN}$} & \multicolumn{4}{|l|}{ GRA } & \multirow{2}{*}{$\begin{array}{l}\text { GRA/ } \\
\text { BCN }\end{array}$} \\
\hline & av. & sd. & $\begin{array}{l}\mathrm{WD} / \\
\mathrm{HD}\end{array}$ & $\begin{array}{l}\text { REG/ } \\
\mathrm{O}\end{array}$ & av. & sd. & $\begin{array}{l}\text { WD/ } \\
\mathrm{HD}\end{array}$ & $\begin{array}{l}\text { REG/ } \\
\mathrm{O}\end{array}$ & \\
\hline Succinic acid (SA; $m / z, 247)$ & 24 & 17 & 2.2 & 2.1 & 37.6 & 20.9 & 1.0 & 1.0 & 1.6 \\
\hline Glutaric acid (GLA; $m / z$ 261) & 4.8 & 3.8 & 2.4 & 2.4 & 9.1 & 5.6 & 1.1 & 1.3 & 1.9 \\
\hline Glyceric acid (GLY; $m / z$ 292) & 15.9 & 10.4 & 1.7 & 2.2 & 24.9 & 15.2 & 0.9 & 1.3 & 1.6 \\
\hline Malic acid (MA; $m / z, 233)$ & 10.8 & 6.7 & 1.4 & 2.0 & 13.7 & 8.3 & 0.7 & 1.0 & 1.3 \\
\hline 2-metylglyceric_acid (MGA; $m / z$ 219) & 3.2 & 1.8 & 1.2 & 1.6 & 3.9 & 2.1 & 0.9 & 1.1 & 1.2 \\
\hline 2-methylthreitol (2MT1; m/z, 219) & 1.8 & 0.8 & 1.2 & 1.2 & 3.4 & 2.1 & 0.7 & 1.0 & 1.9 \\
\hline 2-methylerythritol (2MT2; m/z 219) & 3.7 & 1.3 & 1.1 & 1.2 & 5.6 & 2.7 & 0.9 & 1.1 & 1.5 \\
\hline 3-hydroxyglutaric (HGA; m/z 249) & 6 & 5.7 & 2.7 & 3.6 & 9.8 & 8.5 & 0.9 & 1.6 & 1.6 \\
\hline 3-methylbutane-1,2,3-tricarboxylic acid (MBTCA; $m / z$ 405) & 8.2 & 8.4 & 2.3 & 3.3 & 6.9 & 6.2 & 1.4 & 2.2 & 0.8 \\
\hline Cis pinonic acid (CPA; $m / z, 171)$ & 8.3 & 4.4 & 0.8 & 0.8 & 2.5 & 0.7 & 0.8 & 1.0 & 0.3 \\
\hline Phthalic acid (PHA; $m / z$ 295) & 3.1 & 1.9 & 1.3 & 1.9 & 5.6 & 3.5 & 0.8 & 1.1 & 1.8 \\
\hline Pimelic acid (PIM; m/z 289) & 1.4 & 0.6 & 1.3 & 1.6 & 2.7 & 1.2 & 1.0 & 1.4 & 1.9 \\
\hline Suberic acid (SUB; $m / z, 303)$ & 1.8 & 1.1 & 1.6 & 1.9 & 3.1 & 1.4 & 1.1 & 1.5 & 1.7 \\
\hline Azealic acid (AZA; m/z 317) & 10.4 & 7.1 & 1.7 & 2.4 & 28.6 & 19.3 & 1.4 & 2.2 & 2.8 \\
\hline a-glucose (AGL; $m / z$ 204) & 10.6 & 5 & 0.9 & 1.0 & 13 & 11.2 & 0.7 & 0.8 & 1.2 \\
\hline b-glucose (AGL; m/z 204) & 12 & 6.3 & 0.8 & 1.0 & 14.8 & 14.5 & 0.7 & 0.8 & 1.2 \\
\hline Galactosan (GAL; m/z 204) & 13.6 & 10.9 & 1.7 & 1.8 & 36.1 & 34.5 & 0.7 & 0.9 & 2.7 \\
\hline Mannosan (MAN; m/z 204) & 11.4 & 7 & 1.5 & 1.7 & 23.7 & 22.9 & 0.7 & 1.0 & 2.1 \\
\hline Levoglucosan (LEV; $m / z$ 204) & 119.8 & 81 & 1.7 & 1.8 & 325.8 & 264.7 & 0.9 & 1.3 & 2.7 \\
\hline Benz[a]anthracene (BAA; $m / z$ 228) & 0.1 & 0.06 & 1.7 & 1.6 & 0.56 & 0.58 & 1.0 & 1.0 & 5.6 \\
\hline Chrysene (CHR; m/z 228) & 0.29 & 0.15 & 1.6 & 1.4 & 1.16 & 1.00 & 1.1 & 1.1 & 4.0 \\
\hline Benzo $[\mathrm{b}+\mathrm{j}+\mathrm{k}]$ fluoranthene $(\mathrm{BFL} ; m / z, 252)$ & 0.52 & 0.46 & 1.3 & 1.5 & 1.96 & 1.78 & 1.0 & 1.2 & 3.8 \\
\hline Benzo[e]pyrene (BEP; $m / z, 252)$ & 0.22 & 0.16 & 1.4 & 1.5 & 0.77 & 0.65 & 1.1 & 1.2 & 3.5 \\
\hline Benzo[a]pyrene (BAP; $m / z, 252)$ & 0.13 & 0.11 & 1.9 & 1.7 & 0.68 & 0.68 & 1.1 & 1.2 & 5.2 \\
\hline Indeno[123cd]pyrene (IP; $m / z$ 276) & 0.18 & 0.11 & 1.6 & 1.6 & 0.58 & 0.45 & 1.0 & 1.1 & 3.2 \\
\hline Benzo[ghi]perylene (BGP; $m / z, 276)$ & 0.25 & 0.16 & 1.6 & 1.7 & 0.69 & 0.49 & 1.2 & 1.3 & 2.8 \\
\hline $17 \mathrm{a}(\mathrm{H}) 21 \beta(\mathrm{H})-29$-norhopane (norHOP; $m / z$ 191) & 0.09 & 0.07 & 1.6 & 2.4 & 0.18 & 0.11 & 1.9 & 1.7 & 2.0 \\
\hline $17 \mathrm{a}(\mathrm{H}) 21 \beta(\mathrm{H})$-hopane $(\mathrm{HOP} ; \mathrm{m} / \mathrm{z}, 191)$ & 0.09 & 0.08 & 1.6 & 2.3 & 0.2 & 0.11 & 1.8 & 1.6 & 2.2 \\
\hline
\end{tabular}




\section{Data analysis}

Statistical analysis (Pearson correlations and $t$-tests), graphics, and ratio calculations were performed with the Excel package.

For the source apportionment of the OA, the MCR-ALS method was applied on the augmented database that contained 28 organic tracer compounds and 40 samples. MCR-ALS is based on a bilinear decomposition of the original data set (Tauler 1995). In matrix form, it is expressed as $D(I \times J)=$ $U(I \times N) \mathrm{V}^{\mathrm{T}}(N \times J)+E(I \times J)$, where $D$ is the original data array, with $I$ rows (samples) and $J$ columns (compounds); $U$ is the matrix of scores of dimensions $I \times N$, where $N$ is the reduced number of components; $V^{\mathrm{T}}$ is the matrix of loadings with dimensions $N \times J$; and $E$ is the matrix of residuals not modeled by the $N$ components. The MCR-ALS method decomposes the data matrix using an alternating least squares algorithm under non-negativity constraint (Tauler et al. 2006, 2009).

All data arrangements and pretreatments were performed with MATLAB 7.4 (The Mathworks, Natick, USA), and MATLAB PLS 5.8 Toolbox (Eigenvector Research Inc., Masson, WA, USA) was used for the subsequent multivariate data analysis.

\section{Meteorological data, air-mass back-trajectories, and mixing layer height}

Ambient temperature, relative humidity, and wind speed were obtained from meteorological stations near the sampling sites. During sampling days in $\mathrm{BCN}$, temperature, relative humidity, and wind speed ranged between $4-18{ }^{\circ} \mathrm{C}, 36-88 \%$, and $1.3-6.4 \mathrm{~m} / \mathrm{s}$, respectively, whereas in GRA, these ranged between $3-13{ }^{\circ} \mathrm{C}, 42-82 \%$, and $2.6-9.3 \mathrm{~m} / \mathrm{s}$, respectively. Thus, the average temperatures were similar in both urban areas, although the maximum daily temperatures were higher in BCN (Table 1). The observed temperatures are in range of those observed over the last 3 years for this period of the year. Precipitation in the sampling sites occurred in 3 days, with maximum values below $0.3 \mathrm{~mm}$, which is typical of these Mediterranean cities. In summary, the meteorological conditions were representative of these studied urban areas.

The Lagrangian HYSPLIT 4 model from the National Oceanic and Atmospheric Administration Air Research Laboratory (Stein et al. 2015; Rolph et al. 2017) was used for the determination of the air mass back trajectories and MHs at the sampling sites. This model assumes that there is a wellmixed layer for pollutant transport and dispersion. The MH determinations of this model are comparable to those obtained by LIDAR measurements (Garcia et al. 2007; Sicard et al. 2006; Granados-Muñoz et al. 2012; Bravo-Aranda et al. 2017). Air mass back-trajectories were calculated for sampling days at 12:00 h, 18:00 h, 00:00 h, and 06:00 h local time for $72 \mathrm{~h}$ backwards with 6-h steps. Air-mass back trajectories were used to classify the sampled air masses into regional (24-h back-trajectory less than $500 \mathrm{~km}$ from sampling site), North Atlantic, or European origins (Fig. S1). The analyzed period was characterized by frequent atmospheric stagnation associated with anti-cyclonic synoptic systems over the Iberian Peninsula and the Azores. These stagnant atmospheric conditions resulted in a regional circulation of air masses in $69 \%$ and $59 \%$ of the sampled days in BCN and GRA, respectively. In both cities, the other trajectories were transitions to low atmospheric pressure systems in which the air masses originated from the European continent (EU 19\% BCN; 18\% GRA) or the North Atlantic (NA 13\% BCN; 23\% GRA). A strong coincidence existed between these last transition trajectories and holidays (about $80 \%$ the days), which was similar for regional trajectories and working days.

Concerning the MHs of the sampling days, they were similar at midday (12 h) in both cities (BCN $600 \pm 300 \mathrm{~m}$; GRA $600 \pm 240 \mathrm{~m}$ ). However, important differences were observed at $06 \mathrm{~h}$, and $18 \mathrm{~h}$, and $00 \mathrm{~h}$ with average values of $70 \pm 80 \mathrm{~m}$ and $400 \pm 300 \mathrm{~m} \mathrm{MH}$ in GRA and BCN, respectively. The average 24-h MHs of the samples were $470 \pm 260 \mathrm{~m}$ and $200 \pm$ $100 \mathrm{~m}$ in BCN and GRA, respectively.

\section{Results and discussion}

\section{Particulate matter, organic, and elemental carbon}

The average concentrations ( \pm standard deviation) of PM, OC, $\mathrm{EC}$, and organic tracer compounds, as well as meteorological variables and atmospheric MHs in BCN and GRA are reported in Tables 1 and 2. These tables also contain the ratios of the concentrations in samples that were collected in working days (WD) to those collected in weekends and holidays (HD) and ratios of the concentrations in samples that were collected during regional air masses (REG) to those collected in days with other transition air masses $(\mathrm{O})$.

Daily $\mathrm{PM}_{10}$ were two times higher in GRA than $\mathrm{BCN}$ and higher on WD compared to $\mathrm{HD}(\mathrm{WD} / \mathrm{HD}=1.4$ and $1.2 \mathrm{in}$ $\mathrm{BCN}$ and GRA, respectively) and during regional circulation of air masses compared to days of other transition air masses (REG/O = 1.4 in BCN and 1.5 in GRA, respectively). The $\mathrm{PM}_{10}$ concentrations were in the range of previous measurements in urban sites in Spain and the USA, but lower than those in China and India (Perez et al. 2010; Querol et al. 2013; Yang et al. 2018). They were below the daily limit value of 50 $\mu \mathrm{g} / \mathrm{m}^{3}$ of the EU air quality directive (European Council Directive 2008/50/EC).

The $\mathrm{OC}$ and $\mathrm{EC}$ concentrations were also two times higher in GRA than BCN. The OC concentrations were slightly higher on $\mathrm{WD}(\mathrm{WD} / \mathrm{HD}=1.2)$, while they were clearly higher under more stagnant REG conditions $(\mathrm{REG} / \mathrm{O}=1.6$ and 1.5 in $\mathrm{BCN}$ and GRA, respectively). The EC concentrations were 
higher on WD $(\mathrm{WD} / \mathrm{HD}=2.3$ and $1.7 \mathrm{in} \mathrm{BCN}$ and GRA, respectively) and under REG conditions (REG/O = 2.2 and 1.8 in BCN and GRA, respectively). Overall, the measured $\mathrm{OC}$ and $\mathrm{EC}$ concentrations were in the range of previous urban measurements in Spain (Perez et al. 2010; Querol et al. 2013; Titos et al. 2017), and they were also comparable with the concentrations observed in urban background sites of Mexico City under calm weather condition (Guzmán-Torres et al. 2009).

The $\mathrm{PM}_{10}$ concentrations were significantly correlated with the $\mathrm{OC}$ and EC levels over the complete sampling period, showing higher correlation coefficients in GRA (GRA: $R^{2}=$ 0.85 and $0.75 ; p<0.01)$ than in $\mathrm{BCN}\left(R^{2}=0.50\right.$ and 0.37 , respectively; $p<0.05$; Fig. 2a, b). The mean $\mathrm{OC} / \mathrm{PM}_{10}$ ratios were 0.2 in both cities, without significant differences between days or atmospheric conditions. On the other hand, the $\mathrm{OC} / \mathrm{EC}$ ratios in both cities increased from 2.2 on WD to 4.0 on HD. In general, the OC/EC ratios in diesel emissions and sites that are under direct influence of traffic emissions in Spain range between 1.9 and 2.3 (Querol et al. 2013), suggesting a dominance of diesel motorized vehicle exhausts in the WD. The higher OC/EC ratios observed on HD likely reflected additional OC sources, such as biomass burning emissions or SOA contributions.

\section{PAH}

These toxic hydrocarbons were primary products of incomplete combustion of fossil fuels and biomass (Alves 2008; Galarneau 2008; Iinuma et al. 2007; Rogge et al. 1993a, b; Schauer et al. 2007). The particle-bounded PAHs measured in this study were benz[a]anthracene (BAA), chrysene (CHR), benzofluoranthenes $\left(\sum \mathrm{b}, \mathrm{j}\right.$, and $\mathrm{k}$ isomers; $\left.\mathrm{BFL}\right)$, benzo[e]pyrene (BeP), benzo[a]pyrene (BaP), indeno[123cd]pyrene (IP), and benzo[ghi]perylene (BGP). In GRA, the $\sum \mathrm{PAH}$ concentrations were about four times higher than in BCN (Table 2). The concentrations were in the range of those found in other urban areas of Spain and other cities and semi-rural background areas southern European countries (Alves et al. 2017; van Drooge and Perez-Ballesta2009; van Drooge et al. 2018). Nevertheless, the observed concentrations were lower than those determined in winter in urban areas in the Czech Republic (Krumal et al. 2013) or in the Republic of China (Wang et al. 2009; Liu et al. 2017).

$\mathrm{BaP}$ is the only organic compound in PM that is regulated by law, with an annual target value of $1 \mathrm{ng} / \mathrm{m}^{3}$ (European Council Directive 2004/107/EC). The mean BaP concentrations in these winter samples were 0.68 and $0.13 \mathrm{ng} / \mathrm{m}^{3}$ in GRA and BCN, respectively, below the legal target level in both sites. BaP concentrations and other PAHs were higher in WD and REG conditions in BCN, but very similar in GRA, indicating that the primary emissions from combustion sources decreased on HD and $\mathrm{O}$ in $\mathrm{BCN}$, but very little in GRA.

The most abundant PAH was BFL in both sites, followed by $\mathrm{CHR}, \mathrm{BeP}$, and BGP, which is typically encountered in outdoor air (Ladji et al. 2009; van Drooge and Grimalt 2015). The $\mathrm{BaP}$ levels are relatively higher than $\mathrm{BeP}$ in aerosols from fresh combustion emissions compared to aged aerosols due to photochemical degradation (Galarneau 2008). The average $\mathrm{BaP} /(\mathrm{BaP}+\mathrm{BeP})$ ratios on $\mathrm{WD}$ were 0.41 and 0.44 in $\mathrm{BCN}$ and GRA, respectively, while on HD, they were 0.34 and 0.42 in BCN and GRA, respectively. No difference in ratios was observed between REG and O conditions in GRA (0.43), while the ratios in REG and $O$ conditions were 0.39 and 0.35 in BCN, respectively. These results are consistent with
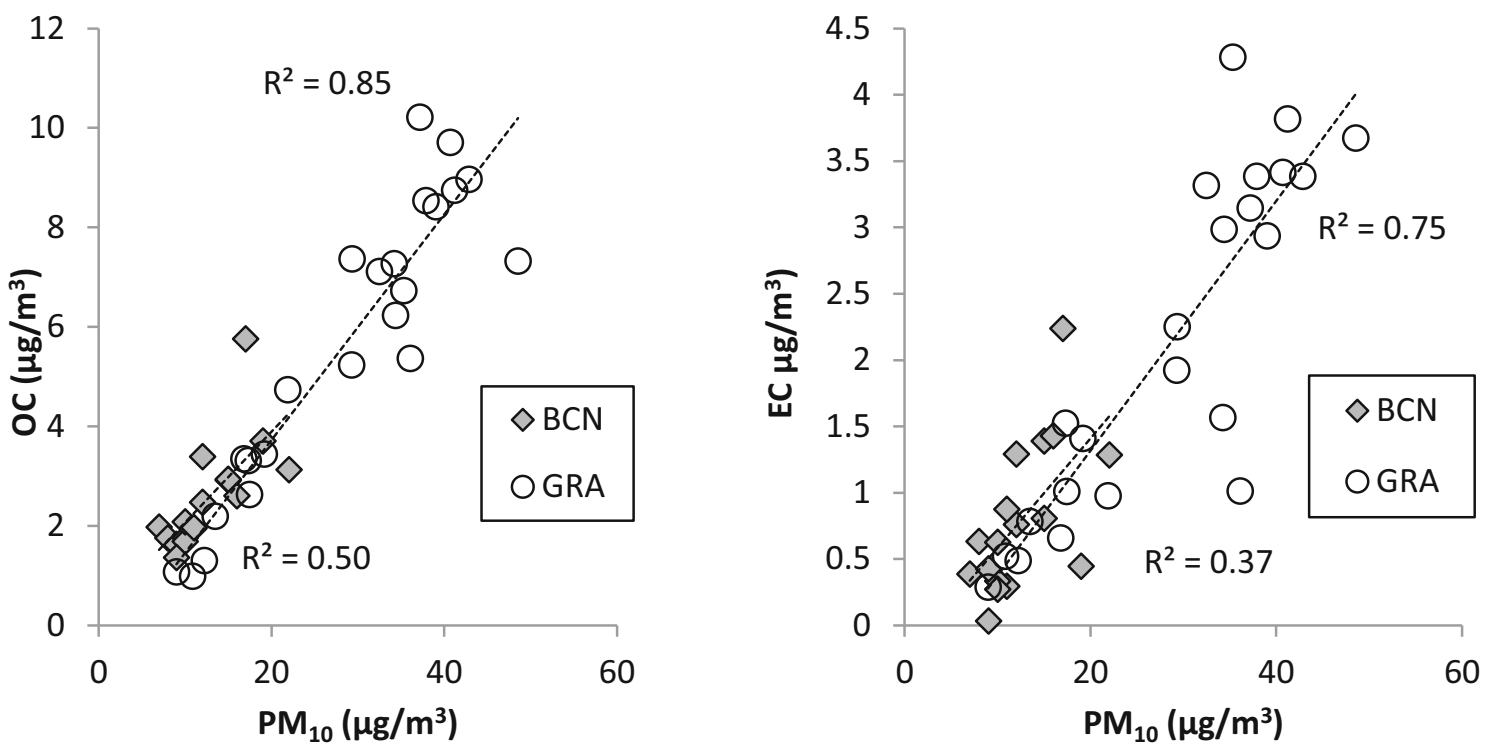

Fig. 2 Correlation between PM10 $\left(\mu \mathrm{g} / \mathrm{m}^{3}\right)$ concentration versus OC and EC concentrations $\left(\mu \mathrm{g} / \mathrm{m}^{3}\right)$ in GRA and BCN 
more fresh combustion PAH contributions in GRA, both on WD and $\mathrm{HD}$, than in $\mathrm{BCN}$, where the influence of fresh combustion emissions decreased on HD.

The isomeric ratio of IP/(IP + BGP) is an indicator of traffic emissions from combustion engines with ratios between 0.2 and 0.3 , while those in biomass burning smoke are around 0.5 (Galarneau 2008; Sicre et al. 1987). The average IP/(IP + $\mathrm{BGP}$ ) ratios were 0.41 and 0.43 on $\mathrm{WD}$ (and $\mathrm{REG}$ conditions) in BCN and GRA, respectively, and 0.44 and 0.48 on HD (and $\mathrm{O}$ conditions) in BCN and GRA, respectively. These ratios indicated higher traffic contributions on WD and REG in both BCN and GRA, while biomass burning emission contributions increased on HD in GRA.

\section{Hopanes}

$17(\mathrm{H}) \alpha, 21(\mathrm{H}) \beta-29$-norhopane (NHOP) and 17(H) $\alpha, 21(\mathrm{H}) \beta-$ hopane (HOP) are present in mineral oils, and the detection of these compounds in the urban atmosphere is related to unburned lubricating oil residues from primary vehicles emissions and fossil fuel combustion (Rogge et al. 1993a; Schauer et al. 2007). The concentrations of these compounds showed high correlations coefficients $\left(R^{2}=0.98 ; p<0.01\right)$. In both sites, the hopanes were also well correlated with the PAH concentrations, as shown in Fig. 3 a for NHOP and BaP, which is consistent with a common traffic source for these compounds and the other PAHs.

The mean $\sum$ hopane concentration in the urban background area of GRA were two times higher than in BCN (Table 2), but they were in the range of those observed in urban areas in Spain, and other cities in Europe and USA, but generally lower than those observed in China (Alier et al. 2013; Jedynska et al. 2014; Krumal et al. 2013; Subramanian et al. 2006; van Drooge and Grimalt 2015; Wang et al. 2009).
The hopane concentrations were higher on WD and on REG, in both cities. They have been proposed as estimators of the contribution of traffic emissions to the OC in the atmosphere (Rogge et al. 1993a; Charron et al. 2019), with NHOP/ OC ratios of $0.2(\mathrm{mg} / \mathrm{g})$ in vehicle emissions (Charron et al. 2019), but two times higher ratios in tunnel experiments (El Haddad et al. 2009). The overall NHOP/OC ratios, in BCN and GRA, are 0.072 and 0.067 , showing similar traffic contributions. These ratios decreased on HD in both cities, which is consistent with the observed $\mathrm{OC} / \mathrm{EC}$ and the isomeric $\mathrm{PAH}$ ratios, indicating a reduction of traffic contributions during holidays.

\section{Anhydrosugars}

The monosaccharide anhydrides levoglucosan (LEV), galactosan (GAL), and mannosan (MAN) are formed by thermal alteration of cellulose and hemi-cellulose and are emitted in relatively large quantities during biomass burning (Simoneit 2002; Fine et al. 2004). In the present study, LEV, MAN, and GAL were well correlated $\left(R^{2}=0.91 ; p<0.01\right)$, and the $\mathrm{LEV} /(\mathrm{MAN}+\mathrm{GAL})$ ratios were 5.4 and 4.8 , in GRA and $\mathrm{BCN}$, respectively, which is consistent with softwood combustion emissions (Fine et al. 2004). The LEV concentrations were three times higher in GRA than BCN (Table 2) and similar to those observed in winter in previous studies in the two cities (Reche et al. 2012; van Drooge et al. 2014; Titos et al. 2017). Moreover, the higher concentrations in GRA were comparable to other rural and urban sites exposed to local biomass burning emissions (Puxbaum et al. 2007; van Drooge and Grimalt 2015).

The LEV concentrations were higher on WD in BCN and slightly higher on HD in GRA. LEV has been used to estimate the relative contribution of biomass burning using the ratios
Fig. 3 a, b Correlation curves between concentrations of benzo[a]pyrene $\left(\mathrm{BaP} ; \mathrm{ng} / \mathrm{m}^{3}\right)$ and a nor-hopanes $\left(\mathrm{ng} / \mathrm{m}^{3}\right)$ and $\mathbf{b}$ levoglucosan $\left(\mathrm{ng} / \mathrm{m}^{3}\right)$ from the analyzed samples from the urban background sites in Barcelona $(\mathrm{BCN})$ and Granada (GRA)
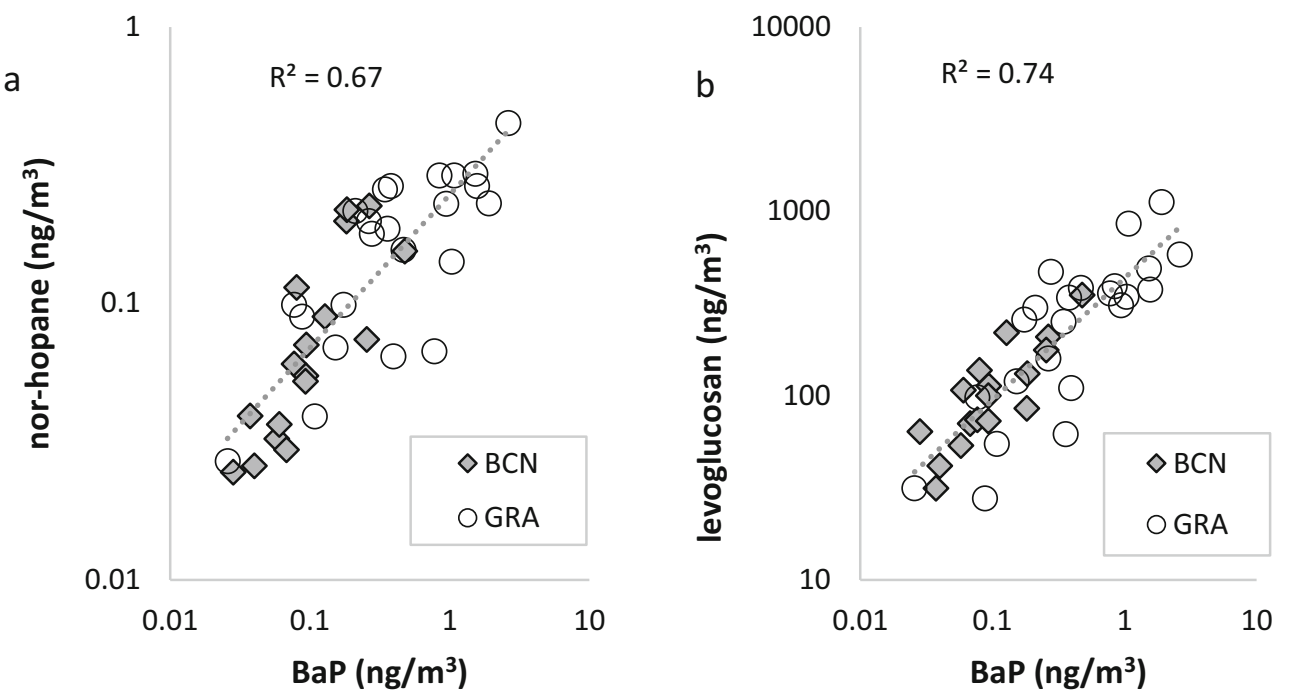
LEV/PM 10 in residential wood burning smoke emissions, 31 $\mathrm{mg} / \mathrm{g}$ (Gonçalves et al. 2011), and LEV/OC in wood burning smoke emissions, e.g., $179 \mathrm{mg} / \mathrm{g}$ (Maenhout et al. 2012). In BCN, these average ratios were $9.6 \mathrm{mg} / \mathrm{g}$ and $48 \mathrm{mg} / \mathrm{g}$, respectively, and in GRA, $11 \mathrm{mg} / \mathrm{g}$ and $57 \mathrm{mg} /$ $\mathrm{g}$, respectively, showing higher contributions of biomass burning in GRA. The ratios were higher on WD in BCN and higher on HD in GRA, indicating a change in emissions. Biomass burning emissions are important contributors to OC and PAHs, but less important contributors to EC compared to traffic emissions (Schauer et al. 2008; Simoneit 2002; Fine et al. 2004). This activity generates more PAHs and char, especially at low temperatures, but less soot carbon, while vehicle combustion engines generate more soot carbon and less PAHs at the higher combustion temperatures. Substantial positive correlations were obtained between BaP and levoglucosan (Fig. 3b), indicating that part of the PAHs and OC concentrations originated from biomass burning. This is consistent with the observed $\mathrm{OC} / \mathrm{EC}$ and isomeric PAH ratios in the cities.

\section{Primary saccharides and polyols}

$\alpha$-glucose (AGL) and $\beta$-glucose (BGL) are important constituents of soil organic matter related to plant tissue and microorganisms, which can enter into the atmosphere not only by wind erosion and up whirling of soil dust, but also by thermal stripping during biomass burning (Medeiros and Simoneit 2007; Samaké et al. 2019; Simoneit et al. 2004).

AGL and BGL were found in all samples with comparable concentrations in both sites (Table 2), and the concentrations were similar to those found in previous studies in $\mathrm{BCN}$ in winter. However, the concentrations were ten times lower than those found in summer samples (van Drooge and Grimalt 2015), indicating lower biological activity in the sampling period and small influence of soil-dust resuspension on the samples. In GRA, the glucose concentrations were correlated with $\operatorname{LEV~}\left(R^{2}=0.58\right.$; $p<0.01)$ which could reflect thermal stripping of these compounds during biomass burning (Medeiros and Simoneit 2007). This correlation was not observed in $\mathrm{BCN}$. On the other hand, the average $\sum$ glucose/OC ratio was higher in BCN $(10 \mathrm{mg} / \mathrm{g})$ than in GRA $(5.5 \mathrm{mg} / \mathrm{g})$ which is consistent with the location of the hi-vol samplers, in a garden in BCN and on a roof in GRA. Influence of soil dust up-whirling by wind was therefore more probable than in the former, with no correlation with biomass burning emissions. The location difference was also consistent with a weak positive correlation between $\sum$ glucose/OC ratios and average wind speed of the samples in $\mathrm{BCN}\left(R^{2}=0.26 ; p<0.05\right)$, while there was no correlation in GRA $\left(R^{2}<0.02\right)$.
Aliphatic, aromatic, and hydroxy dicarboxylic acids

Succinic acid (SA), glutaric acid (GLA), and malic acid (MA) are aged SOA products from VOC oxidation (Heald et al. 2010; Satsumabayashi et al. 1989). Azelaic acid (AZA) is an ozone oxidation product of oleic acid that has been related to food cooking emissions (Kawamura and Ikushima 1993; Moise and Rudich 2002; Robinson et al. 2006). SA and AZA were the most abundant compounds (Table 2), which was also observed in previous studies in Spanish urban areas (Alier et al. 2013; van Drooge et al. 2018). Pimelic acid (PIM) and suberic acid (SUB) were additional oxidation products (van Drooge and Grimalt 2015) in minor concentrations. Phthalic acid esters (PHA) have a dual origin that may originate from combustion (Kawamura and Kaplan 1987) or atmospheric oxidation of aromatic hydrocarbons (Ho et al. 2010; Kawamura and Ikushima 1993; Kawamura and Yasui 2005), and the concentration was higher in GRA than BCN.

SA concentrations in the studied locations were in the range of those observed in other urban areas (Ho et al. 2010; Kawamura and Ikushima 1993; Satsumabayashi et al. 1989; Timonen et al. 2008; Yue and Fraser 2004), although they were lower than those found in the past in sites located downwind Los Angeles in periods of photochemical smog (200$500 \mathrm{ng} / \mathrm{m}^{3}$ : Grosjean et al. 1978), or New Delhi (270-330 ng/ $\mathrm{m}^{3}$ : Miyazaki et al. 2009), and Shanghai (200 $\mathrm{ng} / \mathrm{m}^{3}$ : Yao et al. 2002). In previous studies in BCN and Madrid, the dicarboxylic acid (DCA) levels were similar in urban traffic sites and background sites, indicating that these compounds were more related to regional recirculation and atmospheric secondary processes than local emission sources, such as traffic, although biomass burning contributions could not be excluded (Alier et al. 2013; van Drooge and Grimalt 2015; van Drooge et al. 2018).

In the present study, the aged SOA contributions to OC were similar in the two cities (average $\sum \mathrm{DCA} / \mathrm{OC}=28 \mathrm{mg}$ / $\mathrm{g}$ and $25 \mathrm{mg} / \mathrm{g}$ in BCN and GRA, respectively), but higher on WD and REG in BCN, and slightly higher on HD in GRA (WD/HD and REG/O = 1.3 in BCN and 0.9 in GRA).

\section{Isoprene SOA}

The concentrations of the isoprene SOA tracers, 2-methylthreitol (2MT1), 2-methylerythritol (2MT2), and 2-methylglyceric acid (2MGA), were higher in GRA than $\mathrm{BCN}$ (Table 2) and in the range of those found in previous studies during winter. On the other hand, they were about ten times lower than those measured in summer in $\mathrm{BCN}$ (van Drooge et al. 2018) or background areas (Chan et al. 2010; Ion et al. 2005). The average $\sum$ isoprene SOA/OC ratio was $3.5 \mathrm{mg} / \mathrm{g}$ in BCN and $2.3 \mathrm{mg} / \mathrm{g}$ in GRA, with mean WD/HD ratios of 0.9 and 0.8 , respectively. These results showed a 
formation of isoprene SOA in winter in these urban areas, but with low contribution to OC.

2MT1 and 2MT2 were strongly correlated in the samples $\left(R^{2}=0.83 ; p<0.01\right)$, while the correlation of 2MTs with 2MGA was much weaker $\left(R^{2}=0.25 ; p<0.05\right)$ due to different formation pathways. In former studies (Hoyle et al. 2011; Nguyen et al. 2014; Surratt et al. 2010; Zhang et al. 2007), it was observed that $2 \mathrm{MGA}$ formation is controlled by the concentrations of $\mathrm{NO}$ and $\mathrm{SO}_{2}$ as well as humidity conditions, while 2MTs showed higher levels under very low NO concentrations, or in air masses that are transported towards the urban areas from background areas. In the present study, the 2MGA/2MT ratios were 0.60 and 0.56 on WD and HD, respectively, in BCN and 0.46 and 0.41 on WD and HD, respectively, in GRA. These ratios were 0.63 and 0.40 under REG and $\mathrm{O}$ conditions in $\mathrm{BCN}$, respectively, and 0.43 under both conditions in GRA. The lower ratios on HD and $\mathrm{O}$ indicated the transport of 2MT from background areas, while the higher ratios in WD indicated enhanced formation of 2MGA with respect to $2 \mathrm{MTs}$ in the presence of traffic.

\section{a-Pinene SOA tracers}

Volatile $\alpha$-pinene is emitted by conifer trees, yielding cispinonic acid (CPA) as primary oxidation product. CPA has been linked to new particle formation (NPF) not only in forest areas, but also in urban areas (Alier et al. 2013; Laaksonen et al. 2008; O’Dowd et al. 2002; van Drooge et al. 2018). 3Hydroxyglutaric acid (3HGA) and 3-methyl-1,2,3butanetricarboxylic acid (MBTCA) are formed as additional oxidation processes of CPA and their occurrence is and related to aged biogenic SOA (Claeys et al. 2007; Kubatova et al. 2000; Muller et al. 2012; Szmigielski et al. 2007).

CPA had higher concentrations in BCN than in GRA (Table 2), while the concentrations of 3HGA and MBTCA were similar in both cities. The observed pinene SOA concentrations were similar to those found in previous studies in BCN (Alier et al. 2013; van Drooge et al. 2018; Minguillon et al. 2016) and wintertime samples from Oporto (Alves et al. 2014). There was no correlation between CPA concentrations and the other $\alpha$-pinene SOA tracers, while there was a substantial correlation between 3HGA and MBTCA $\left(R^{2}=0.56 ; p\right.$ $<0.05)$, which is in agreement with their different formations pathways.

Fresh SOA from pinene oxidation contributions to $\mathrm{OC}$ were higher in $\mathrm{BCN}(\mathrm{CPA} / \mathrm{OC}=3.9 \mathrm{mg} / \mathrm{g})$ than GRA ( $\mathrm{CPA} / \mathrm{OC}=0.7 \mathrm{mg} / \mathrm{g})$, and this excess of fresh versus aged biogenic SOA in BCN was supported by the CPA/(3HGA + MBTCA) ratio. In $\mathrm{BCN}$, this ratio was higher on $\mathrm{HD}(1.7)$ and $O$ (2.1) than on WD and REG (0.7). On the other hand, in GRA, this ratio was 0.3 , with slightly higher ratios on HD (0.5) and $\mathrm{O}(0.4)$. Moreover, in BCN, the maximum CPA concentration $\left(21 \mathrm{ng} / \mathrm{m}^{3}\right)$ and $\mathrm{CPA} /(3 \mathrm{HGA}+\mathrm{MBTCA})$ ratios were observed during the Christmas holidays, when the overall air pollution indicator concentrations were low $\left(\mathrm{PM}_{10}=7-\right.$ $10 \mu \mathrm{g} / \mathrm{m}^{3}$ ), and the air temperatures were the highest observed in this study $\left(15-18^{\circ} \mathrm{C}\right)$. The clean air conditions in combination with high air temperatures are the conditions for NPF (Brines et al. 2015) in which cis-pinonic acid may be involved (Alier et al. 2013; Laaksonen et al. 2008; O’Dowd et al. 2002; van Drooge et al. 2018). This process may play a role of importance on the OA in BCN, while in GRA, this will probably be not significant due to the excess of primary and aged secondary aerosols.

\section{Source apportionment of organic aerosol}

Multivariate curve resolution (MCR-ALS) was applied on the total database ( 28 compounds $\times 40$ samples). The calculations identified four components that explained $90 \%$ of the total variance. Two components were related to the primary OA of combustion sources (traffic emissions and biomass burning), while the other two were related to aged and fresh SOA. The chemical compositions of the components (loadings) are plotted in Fig. 4, while the score values are shown in Fig. 5a. Additional components did not show further plausible relationships between the organic compounds and sources or processes, while their reduction gave rise a mixed component of traffic and biomass burning encompassing an evident loss of information. The sum of scores of the four components was correlated with the OC concentrations in the filter samples $\left(R^{2}\right.$ $=0.78 ; p<0.01$; Fig. $5 \mathrm{~b}$ ), so the resolved components in this study reflected the OA composition. This aspect is very relevant because the sum of the average concentrations of molecular tracers, $110 \mathrm{ng} / \mathrm{m}^{3}$ and $95 \mathrm{ng} / \mathrm{m}^{3}$ in BCN and GRA, respectively, only described $4.4 \%$ and $1.7 \%$ of the OC in these two respective cities. However, the observed correlation indicates that the changes in $\mathrm{OC}$ in both cities, including the nonamenable GC polymeric fractions, are monitored by the analyzed molecular tracers.

The first component was the traffic POA (30\% of the total variance), since it was composed by primary tracer compounds from urban traffic emissions, such as hopanes $(56 \%$ of the total concentration variance of these compounds in the samples) and PAHs (70\% of total variance) (Fig. 4a). Higher score values were obtained in GRA compared to BCN (Fig. 5a, c), and a substantial correlation was observed between the score values of the traffic POA component and the nor-hopane/OC ratio $\left(R^{2}=0.68 ; p<0.01\right.$; Fig. $\left.5 \mathrm{~d}\right)$, relating this component to traffic emissions in the urban area. Nevertheless, this component also contained biomass burning and SOA tracer compounds, e.g., LEV, MAN, GAL, 2MGA, 2MT1, PIM, SUB, and AZA (30\% of variance), which was caused by collinearity of the organic tracer compound concentrations in the urban atmosphere. In $\mathrm{BCN}$, the score values of this component contributed to $12 \%$ of the sum of scores, 

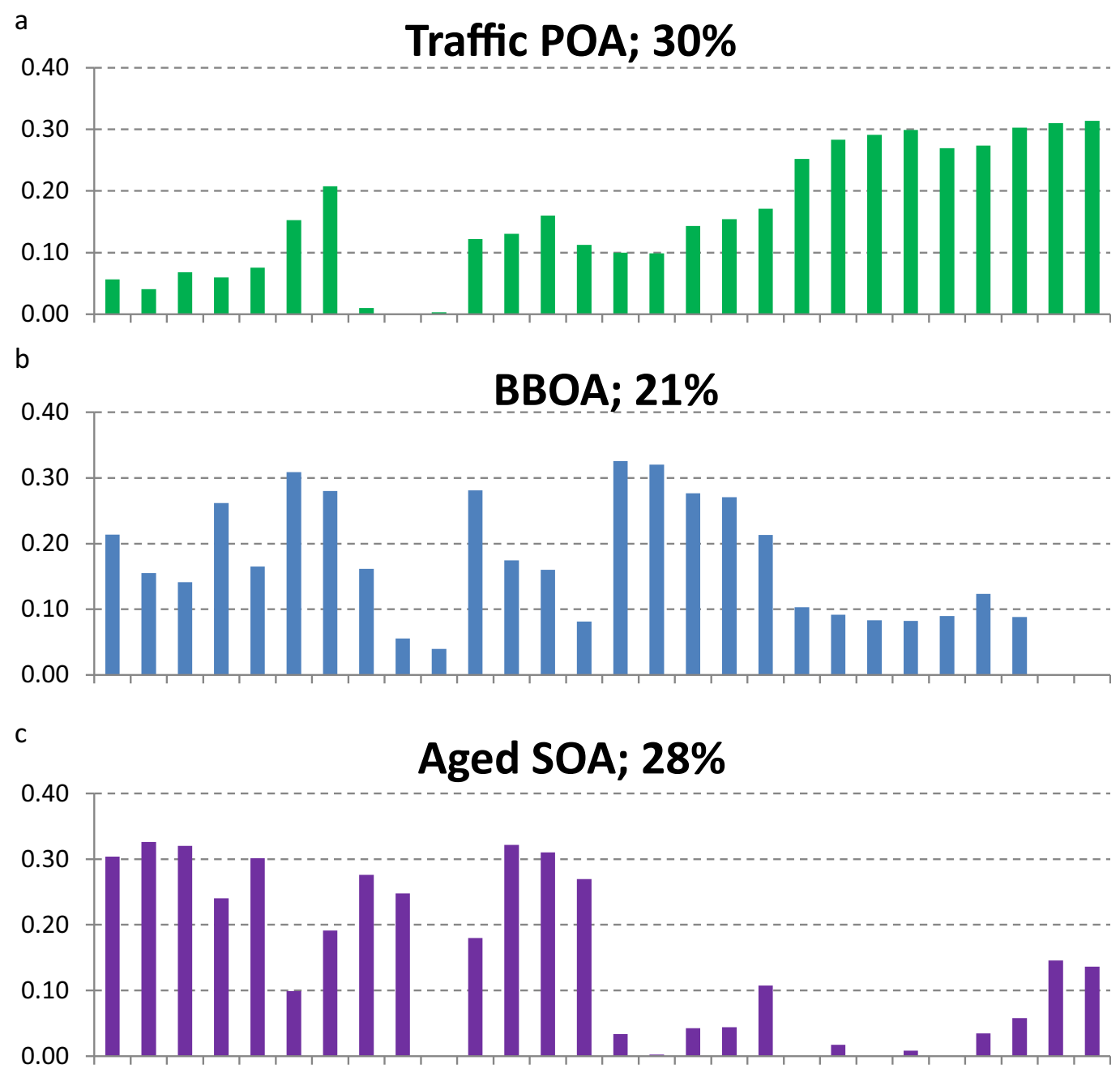

d Fresh Pin SOA; 4\%

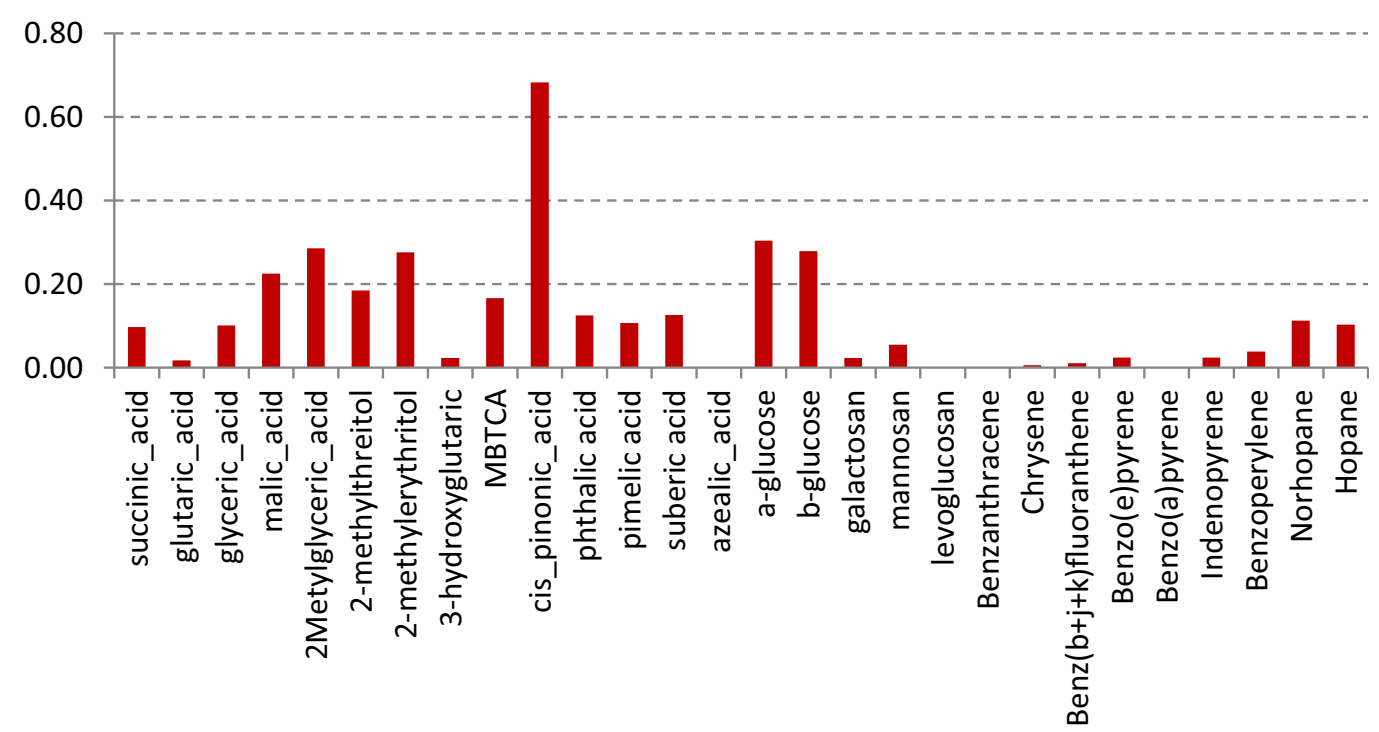

Fig. 4 a, b MCR-ALS loading of components in augmented database from Barcelona (BCN) and Granada (GRA) 


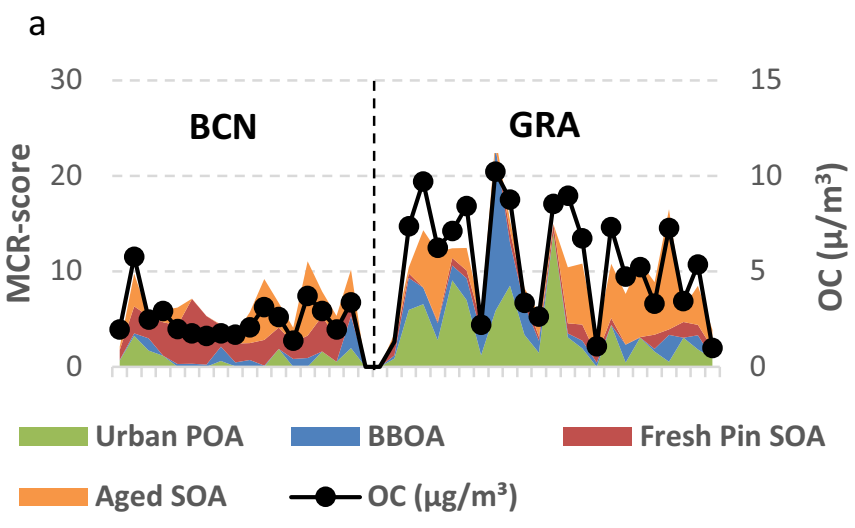

b

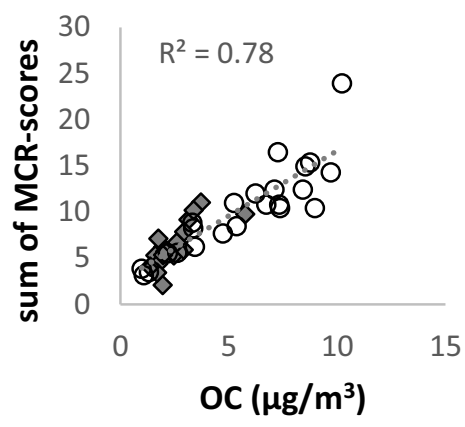

C
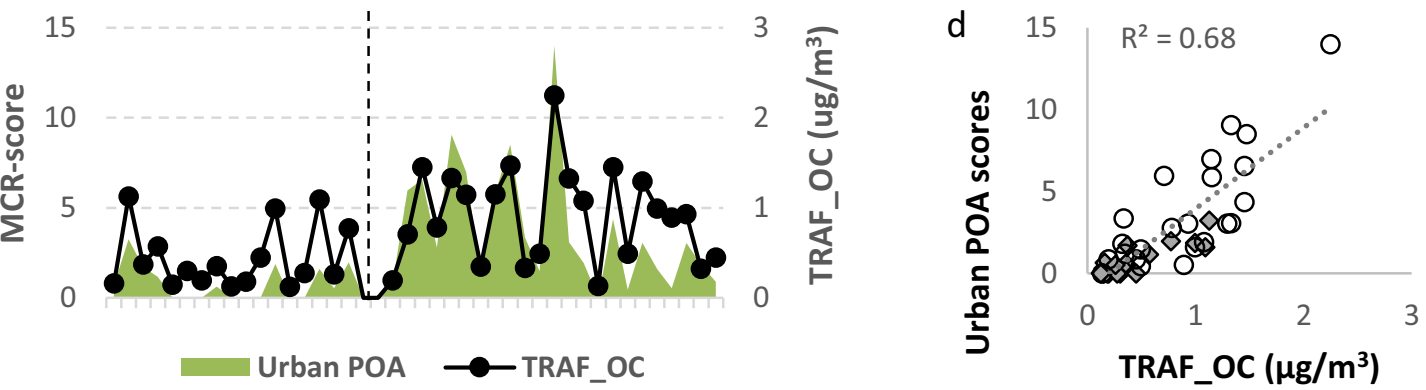

e
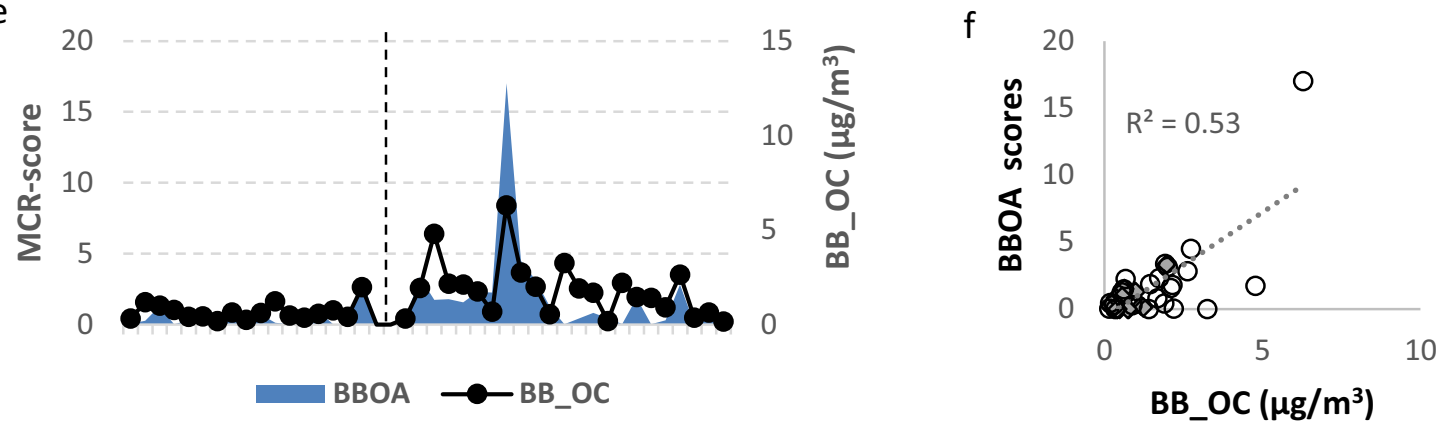

g

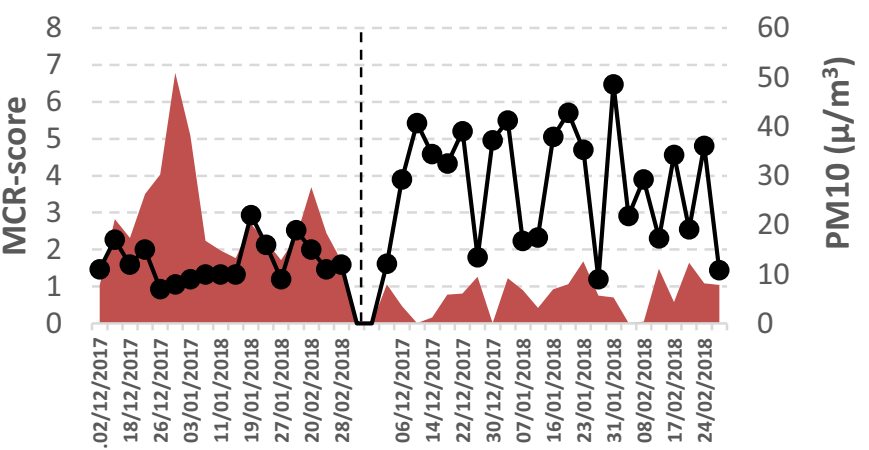

h

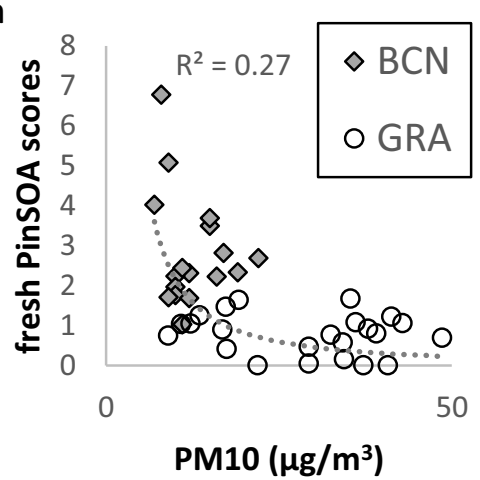

Fig. $5 \mathbf{a}-\mathbf{h}$ a MCR-ALS score values of the four components, $\mathbf{b}$ relationship between the sum of scores and the OC concentrations $\left(\mu \mathrm{g} / \mathrm{m}^{3}\right), \mathbf{c}, \mathbf{d}$ MCR-ALS score values of traffic POA versus TRAF OC from norhopane/OC ratio, and $\mathbf{e}, \mathbf{f M C R}-\mathrm{ALS}$ score values of $\mathrm{BBOA}$ versus $\mathrm{BB}$

OC from levoglucosan/OC ratio. $\mathbf{g}, \mathbf{h}$ MCR-ALS score values from fresh pinene SOA was related to PM10 concentration in Barcelona (BCN) and Granada (GRA) 
which was assumed to be equivalent to total OA and OC. This contribution was similar to the one obtained from the norhopane/OC ratio (16\%) and also showed higher contributions on WD $(\mathrm{WD} / \mathrm{HD}=1.5)$ and REG $(\mathrm{REG} / \mathrm{O}=2.0)$. In GRA, the contribution of the traffic POA to OA was $37 \%$, with higher score values on WD $(\mathrm{WD} / \mathrm{HD}=1.6)$ and $\mathrm{REG}(\mathrm{REG} / \mathrm{O}=$ 1.4). This contribution was higher than the one obtained from the nor-hopane/OC ratio (18\%), and this difference could be caused by the presence of biomass burning emissions and SOA contributions. Among all the four components, the traffic POA component score values showed the best correlations with $\mathrm{PM}_{10}\left(R^{2}=0.47\right)$, OC $\left(R^{2}=0.58\right)$, and $\mathrm{EC}\left(R^{2}=0.48\right)$, indicating the relevance of this component to the overall air quality in the urban areas.

The second component (Fig. 4b), BBOA (21\% of the total variance), consisted of the tracer compounds of biomass burning, i.e., levoglucosan, mannosan, and galactosan $(51 \%$ of total BBOA tracer variance), as well as $\alpha$ - and $\beta$-glucose (44\%) from thermal stripping of vegetation. It also contained PAH (23\%), DCAs and polyols (22\%), and PHA (40\%), which could be primary emitted from biomass burning, or SOA of biomass smoke. Hopanes were not present in this component, thus excluding traffic contributions. The score values of BBOA were higher in GRA than BCN, with peak values in the Christmas holidays in GRA (Fig. 5e). The BBOA contributed by $20 \%$ to the OA in GRA and $9 \%$ in $\mathrm{BCN}$. The score values showed a substantial correlation with the levoglucosan/OC ratios $\left(R^{2}=0.53 ; p<0.05\right.$; Fig. 5f), although the BBOA contributions to OA by MCR-ALS were lower than those obtained with the levoglucosan/OC ratios ( $29 \%$ and $26 \%$ for GRA and $\mathrm{BCN}$, respectively). In the MCR-ALS source apportionment analysis, the overall contribution of BBOA component could have been underestimated since part of the biomass burning tracer compounds were also present in the first traffic POA component. The BBOA score values increased on WD in $\mathrm{BCN}(\mathrm{WD} / \mathrm{HD}=1.7)$ and on $\mathrm{HD}$ in GRA (WD/HD = 0.2). In this last city, this ratio was much higher than the biomass burning tracer concentrations (0.9; Table 1), which again points to an underestimation of the BBOA component scores due to mixing with the traffic POA component on WD.

The third component (Fig. 4c), aged SOA (28\% of the total variance), consisted mainly of aged biogenic and anthropogenic secondary organic aerosol species, such as DCAs (50\% of total DCAs), and $\alpha$-pinene (HGA, 59\%; MBTCA $53 \%)$, as well as MA (31\%), and glyceric acid (51\%). The oxidation products of isoprene were represented by MGA $(36 \%)$, while the $2 \mathrm{MT}$ contributions were much lower (17\%). This component also contained some traces of biomass burning emissions (22\% of levoglucosan) as well as traffic emissions ( $25 \%$ of hopanes), indicating that the multivariate model did not entirely resolve this SOA component from the POA components, and that primary emissions could have been involved in the formation of aged SOA. This finding was supported by the higher scores values and OA contributions on REG ( $42 \%$ of OA in both cities) than on $\mathrm{O}(15 \%$ in $\mathrm{BCN} ; 26 \%$ in GRA). Higher score values and contributions were observed on WD ( $40 \%$ of OA in both cities) compared to HD $(25 \%)$. The average contributions to the OA were similar in BCN and GRA ( $35 \%$ of OA), showing that the aged SOA contributions to the OA were relevant in winter in both cities.

The fourth component (Fig. 4d), fresh pinene SOA (fresh pinSOA; $4 \%$ of the total variance), was predominantly not only composed by CPA (94\%), but also contained traces of biogenic SOA (2HGA, 2MT, MBTCA 30\%) and primary biogenic OA (glucose 40\%). As mentioned above, CPA is a first oxidation product of $\alpha$-pinene, and the occurrence has been linked to NPF in high-insolation urban areas under clean-air conditions (Alier et al. 2013; Laaksonen et al. 2008; O'Dowd et al. 2002; van Drooge et al. 2018). This component showed much higher contributions and score values in $\mathrm{BCN}$ (44\% of OA) than in GRA ( $8 \%$ of OA). In GRA, the score values and contributions were low in all samples (7-9\% of OA), independently of days and atmospheric conditions. On the other hand, in $\mathrm{BCN}$, they increased from $34 \%$ on WD to $59 \%$ on $\mathrm{HD}$, with a clear peak during the Christmas holidays in BCN (80\% of OA; Fig. $5 \mathrm{~g}$ ). As mentioned before, the overall air pollution variable showed low air pollutant concentrations in this period. Furthermore, the air temperature was higher than in the rest of the sampling days, which may lead to appropriate conditions for NPF in BCN (Brines et al. 2015). In fact, this fresh pinSOA component was the only one showing an anti-correlation with the $\mathrm{PM}_{10}\left(R^{2}=0.27 ; p<0.05\right.$; Fig. 5h) and OC concentrations $\left(R^{2}=0.24 ; p<0.05\right)$ and a positive correlation with ambient air temperatures $\left(R^{2}=0.23 ; p<0.05\right)$ in the studied period. $\alpha$ Pinene is the most abundant biogenic VOC in the western Mediterranean Basin, even in winter (Seco et al. 2011). In $\mathrm{BCN}$, an important source area for $\alpha$-pinene could be the large pine forest of the natural park of Collserola located northwest at less than $1 \mathrm{~km}$ distance from the sampling site. Forested areas and elevated air temperatures enhance the occurrence of biogenic organic compounds in the urban atmosphere (Samaké et al. 2019), while general clean-air conditions enhance the formation of CPA acid and NPF (Laaksonen et al. 2008; O’Dowd et al. 2002).

\section{Air pollution in relation to atmospheric $\mathrm{MH}$}

Joint evaluation of chemical composition and tracer/OC ratios shows that the contribution of traffic emissions and biomass burning was similar on WD in both cities and constituted about $50 \%$ of OC. The biomass burning contributions increased on HD in GRA (33\%), while traffic contributions decreased on HD in both cities (12\%). The remaining 50\% of the OC could be considered secondary OA (SOA) (Fig. 6a). 
Based on the MCR-ALS analysis, $57 \%$ of OA in GRA was related to combustion sources $(37 \%$ traffic $+20 \%$ biomass burning), while $43 \%$ was SOA (37\% aged SOA $+8 \%$ fresh pinene SOA). In BCN, $21 \%$ of OA was linked to combustion sources $(12 \%$ traffic $+9 \%$ biomass burning), while $79 \%$ was $\mathrm{SOA}(35 \%$ aged $\mathrm{SOA}+44 \%$ fresh pinene $\mathrm{SOA})$. Therefore, in this study, the main differences concerning the air quality in BCN and GRA were related to higher concentration levels of pollutants in GRA than BCN (about a factor two), and higher contributions of primary $\mathrm{OA}$ from combustion sources in GRA, while BCN showed higher contributions of fresh pinene SOA in the urban background air.

The differences among source contributions were directly related to each other and to the atmospheric conditions of each city. In particular, the mixing layer heights $(\mathrm{MH})$ in the cities might play a crucial role. In $\mathrm{BCN}$, the $\mathrm{MHs}$ were slightly higher on HD $(530 \mathrm{~m})$ than WD $(415 \mathrm{~m})$, which was also observed in GRA (215 m HD; 200 m WD) (Fig. 6a, b).
These differences between MHs in BCN and GRA were also observed on REG (BCN 445 m; GRA $162 \mathrm{~m}$ ) and O (BCN $516 \mathrm{~m}$; GRA $255 \mathrm{~m}$ ). The overall lower $\mathrm{MH}$ in GRA was related to its continental climate influence, leading to a stronger nocturnal temperature inversion, especially under stagnant weather conditions. In $\mathrm{BCN}$, the direct influence of Mediterranean Sea impeded strong nocturnal inversions, resulting in higher $\mathrm{MH}$ (Sicard et al. 2006, Arruda et al. 2018). Hence, the overall lower MH in GRA (200 m) compared to BCN $(460 \mathrm{~m})$ led to higher concentrations of air pollutants in a thinner airshed (Fig. 6a, b). On the other hand, the higher contributions of fresh pinene SOA in $\mathrm{BCN}$ is probably related with cleaner air conditions (low $\mathrm{PM}_{10}$, OC, and EC concentrations), due to the lower contributions of traffic and biomass burning on HD in BCN (Fig. 6b). Other factors, such as higher temperatures, may also have contributed to enhanced fresh pinene SOA through new particle formation as seen in previous studies in the city (Brines et al. 2015). The
Fig. 6 a, b Values of a OC from traffic (OC traffic) and biomass burning (OC_OC) as well as assumed secondary $\mathrm{OC}$ (OC secondary), and the mixing height of the atmosphere (MH) on working days, holidays, and Christmas holidays, and bMCRALS scores of the components from traffic (traffic POA), biomass burning (BBOA), aged secondary organic aerosol (aged SOA) and fresh pinene secondary organic aerosol (fresh pin SOA), and the MH on working days, holidays and Christmas holidays a

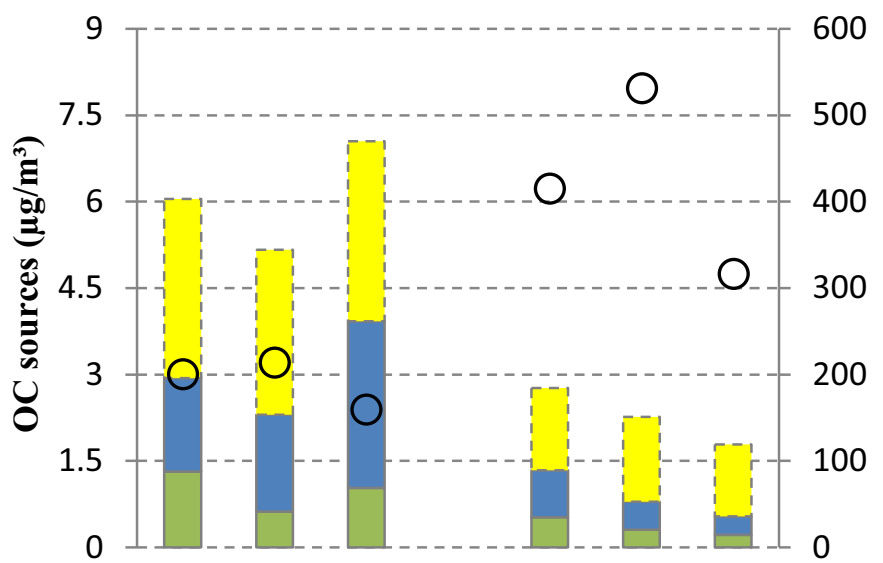

b

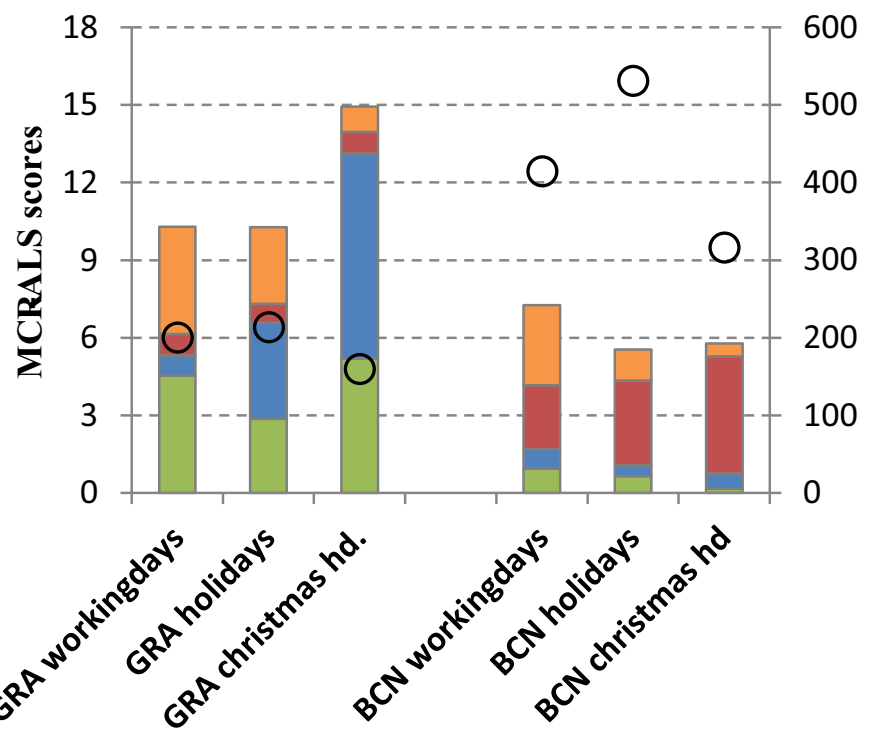

00

500

400 $\mathrm{OC} B \mathrm{BB}$ $\square$ OC_traffic 
low air pollution was in this case probably more important than the MH, since the highest fresh pinene SOA contributions and concentrations were observed during the Christmas holidays when the MH was lower than the rest of the days ( $350 \mathrm{~m}$ versus $460 \mathrm{~m}$; Fig. 6b). In GRA, during the Christmas holidays, the MH was also low (200 m; Fig. 6b), and the airmass back trajectories for these days were from the North Atlantic for both urban areas (Fig. S1). This indicated that the origins of the air masses were similar, but that the influence of regional and local source emissions had different impact on the SOA formation, especially on fresh pinene SOA. In BCN, North Atlantic trajectories predominated and low air pollution concentrations were observed (Fig. 6a, b). In GRA, under conditions of dominance of North Atlantic air masses on Christmas holidays (Fig. S1), an increase of BBOA was observed (Fig. 6b), probably due to biomass burning in agricultural fields located northwest of the urban area (Titos et al. 2017).

The presence of aerosols also reduced the capacity for NPF and fresh pinene SOA formation, while low air pollution conditions favored the formation of new particles from nucleation (O'Dowd et al. 2002). Otherwise, in the presence of existing source emissions, the formation of aged SOA was promoted through heterogeneous reaction and condensation. In these situations, aged SOA dominated and primary OA from combustion sources accumulated, especially at low atmospheric MH.

\section{Conclusions and implications}

The air pollution indicators, i.e., $\mathrm{PM}_{10}, \mathrm{OC}$, and $\mathrm{EC}$, were about two times higher in GRA than BCN during the EMEP sampling campaign in winter 2017-2018. The $\mathrm{PM}_{10}$ levels were below the legal limit value in all samples. The mixing layer height (MH) in GRA (200 m) was about two times lower than in BCN $(460 \mathrm{~m})$, due to the geographical differences (continental versus coastal climate). This lower MH partly explained the higher air pollution levels in GRA compared to $\mathrm{BCN}$.

Source apportionment of the organic database showed four organic aerosol components, with different contributions in the two sites. POA from vehicle traffic emissions and biomass burning were more important in GRA (50\% of OA) than in BCN (20\%). The contribution of biomass burning increased on HD with respect to WD in GRA, while the primary combustion emissions decrease on holidays in BCN. The primary emissions from traffic and biomass burning were responsible for the presence of toxic PAHs in the atmosphere in both sites. Benzo[a]pyrene, the only regulated $\mathrm{PAH}$, showed mean concentrations of 0.13 and $0.68 \mathrm{ng} / \mathrm{m}^{3}$ in $\mathrm{BCN}$ and GRA, respectively.
BBOA could be underestimated in the MCR-ALS source apportionment method due to strong correlations between tracer compounds from traffic and biomass burning sources. The MCR-ALS method resulted in about two times higher combustion emission contributions to $\mathrm{OA}$ in GRA than $\mathrm{BCN}$, although the individual tracer to $\mathrm{OC}$ ratios indicated similar contributions in both cities. This result underlines one of the limitations of the applied source apportionment method in a database where the organic tracer compound concentrations show strong collinearities. In the MCR-ALS method that was used here, only the soft constraint of non-negativity was applied and unique component solutions are not guaranteed (Tauler et al. 2006, 2009).

Generally, the oxidized organic aerosol and SOA made up $40 \%$ of the OA in GRA and $80 \%$ in BCN, which highlight the importance of this type of aerosol in Mediterranean urban areas in winter. Aged SOA contributions were similar in both cities (35\% of OA). Conversely, fresh secondary organic aerosol from $\alpha$-pinene oxidation (fresh pin SOA) was more abundant in BCN (44\% of OA) than in GRA (8\%). Likewise, the strong significance of fresh pinene $\mathrm{SOA}$ in $\mathrm{BCN}$ was related to higher concentration of cis-pinonic acid and probably related to the NPF events under clean-air conditions and elevated air temperatures (Alier et al. 2013; Brines et al. 2015).

The MH played an important role on the concentrations and the variations in the chemical composition of the OA, such as the higher concentrations of air pollutants in thinner air layers. However, thicker MH may have an influence on higher generation of SOA, as observed in $\mathrm{BCN}$ from the higher concentrations of pinene SOA when the contributions of traffic and biomass burning were low.

Supplementary Information The online version contains supplementary material available at https://doi.org/10.1007/s11356-021-16366-0.

Author contribution BL van Drooge: methodology, statistical analysis, data analysis, and writing original draft preparation; Roger Garatachea: formal analysis; C Reche: data collection; G Titos: supervision, reviewing, and editing; A Alastuey: conceptualization, supervision, reviewing, and editing; $\mathrm{H}$ Lyamani: data collection; L AladosArboledas: data collection; X Querol: reviewing and editing; J.O Grimalt: supervision, reviewing, and editing. All authors have read and agreed to the published version of the manuscript.

Funding Financial support for this study was provided by the Cooperative Programme for Monitoring and Evaluation of the LongRange Transmission of Air Pollution in Europe (EMEP) and the European Union's Horizon 2020 research project ACTRIS2 (654109) and supported by research projects from the Plan Nacional de IyD of the Spanish Ministry of Science and Innovation INTEMPOL (PGC2018-102288-B-I00), HOUSE (CGL2016-78594-R), and BioCloud (RTI2018.101154.A.I00). IDAEA-CSIC is a Severo Ochoa Centre of Research Excellence (Spanish Ministry of Science and Innovation, CEX2018-000794-S). 
Data availability Not applicable.

\section{Declarations}

Ethics approval Not applicable.

Consent to participate Not applicable.

Consent for publication Not applicable.

Conflict of interest The authors declare no competing interests

\section{References}

Alier M, Van Drooge BL, Dall'Osto M, Querol X, Grimalt JO, Tauler R (2013) Source apportionment of submicron organic aerosol at an urban background and a road site in Barcelona (Spain) during SAPUSS. Atmos Chem Phys 13:10353-10371. https://doi.org/10. 5194/acp-13-10353-2013

Alves CA (2008) Characterisation of solvent extractable organic constituents in atmospheric particulate matter: an overview. An Acad Bras Cienc 80:21-82. https://doi.org/10.1590/S000137652008000100003

Alves C, Nunes T, Vicente A, Gonçalves C, Evtyugina M, Marques T, Pio C, Bate-Epey F (2014) Speciation of organic compounds in aerosols from urban background sites in the winter season. Atmos Res 150:57-68. https://doi.org/10.1016/j.atmosres.2014.07.012

Alves CA, Vicente AM, Custódio D, Cerqueira M, Nunes T, Pio C, Lucarelli F, Calzolai G, Nava S, Diapouli E, Eleftheriadis K, Querol X, Bandowe BAM (2017) Polycyclic aromatic hydrocarbons and their derivatives (nitro-PAHs, oxygenated PAHs, and azaarenes) in PM2.5 from Southern European cities. SciTotal Env 595:494-504. https://doi.org/10.1016/j.scitotenv.2017.03.256

Arruda M, G, Guerrero-Rascado JL, Bravo-Aranda JA, Benavent-Oltra JA, Ortiz-Amezcua P, Róman R, Bedoya-Velásquez AE, Landulfo E, Alados-Arboledas L (2018) Study of the planetary boundary layer by microwave radiometer, elastic lidar and Doppler lidar estimations in Southern Iberian Peninsula. Atmos Res 213:185-195. https://doi.org/10.1016/j.atmosres.2018.06.007)

Bi X, Simoneit BRT, Sheng G, Ma S, Fu J (2008) Composition and major sources of organic compounds in urban aerosols. Atmos Res 88: 256-265. https://doi.org/10.1016/j.atmosres.2007.11.017

Bravo-Aranda JA, de Arruda Moreira G, Navas-Guzmán F, GranadosMuñoz MJ, Guerrero-Rascado JL, Pozo-Vázquez D, ArbizuBarrena C, Olmo Reyes FJ, Mallet M, Alados Arboledas L (2017) A new methodology for PBL height estimations based on lidar depolarization measurements: analysis and comparison against MWR and WRF model-based results. Atmos Chem Phys 17:6839-6851. https://doi.org/10.5194/acp-17-6839-2017

Brines M, Dall'Osto M, Beddows DCS, Harrison RM, Gómez-Moreno F, Núñez L, Artíñano B, Costabile F, Gobbi GP, Salimi F, Morawska L, Sioutas C, Querol X (2015) Traffic and nucleation events as main sources of ultrafine particles in high-insolation developed world cities. Atmos Chem Phys 15:5929-5945. https://doi. org/10.5194/acp-15-5929-2015

Brines M, Dall'Osto M, Amato F, Minguillón MC, Karanasiou A, Grimalt JO, Alastuey A, Querol X, van Drooge BL (2019) Source apportionment of urban PM1 in Barcelona during SAPUSS using organic and inorganic components. Environ Sci Pollut Res 26: 32114-32127. https://doi.org/10.1007/s11356-019-06199-3

Burnett RT, Pope CA 3rd, Ezzati M, Olives C, Lim SS, Mehta S, Shin HH, Singh G, Hubbell B, Brauer M, Anderson HR, Smith KR,
Balmes JR, Bruce NG, Kan H, Laden F, Pruss-Ustun A, Turner MC, Gapstur SM et al (2014) An integrated risk function for estimating the global burden of disease attributable to ambient fine particulate matter exposure. Environ Health Perspect 2014(122): 397-403. https://doi.org/10.1289/ehp.1307049

Cavalli F, Viana M, Yttri KE, Genberg G, Putaud J-P (2010) Toward a standardised thermal-optical protocol for measuring atmospheric organic and elemental carbon: the EUSAAR protocol. Atmos Meas Tech 3:79-89. https://doi.org/10.5194/amt-3-79-2010

Chan MN, Surratt JD, Claeys M, Edgerton ES, Tanner RL, Shaw SL, Zheng M, Knipping EM, Eddingsaas NC, Wennberg PO, Seinfeld JH (2010) Characterization and quantification of isoprene-derived epoxydiols in ambient aerosol i the southeastern United States. Environ Sci Technol 44:4590-4596. https://doi.org/10.1021/ es $100596 b$

Charron A, Polo-Rehn L, Besombes J-L, Golly B, Buisson C, Chanut H, Marchand N, Guillaud G, Jaffrezo J-L (2019) Identification and quantification of particulate tracers of exhaust and non-exhaust vehicle emissions. Atmos Chem Phys 19:5187-5207. https://doi.org/ 10.5194/acp-19-5187-2019

Claeys M, Szmigielski R, Kourtchev I, Van Der Veken P, Vermeylen R, Maenhaut W, Jaoui M, Kleindienst TE, Lewandowski M, Offenberg JH, Edney EO (2007) Hydroxydicarboxylic acids: Markers for secondary organic aerosol from the photooxidation of $\alpha$-pinene. Environ Sci Technol 41:1628-1634. https://doi.org/10.1021/ es0620181

Cohen AJ, Brauer M, Burnett R, Anderson HR, Frostad J, Estep K, Balakrishnan K, Brunekreef B, Dandona L, Dandona R, Feigin V, Freedman G, Hubbell B, Jobling A, Kan H, Knibbs L, Liu Y, Martin $\mathrm{R}$, Morawska L et al (2017) Estimates and 25-year trends of the global burden of disease attributable to ambient air pollution: an analysis of data from the Global Burden of Diseases Study 2015. Lancet 389:1907-1918. https://doi.org/10.1016/S0140-6736(17) 30505-6

Donahue NM, Robinson AL, Pandis SN (2009) Atmospheric organic particulate matter: from smoke to secondary organic aerosol. Atmos Environ 43:94-106. https://doi.org/10.1016/j.atmosenv. 2008.09.055

El Haddad I, Marchand N, Dron J, Temime-Roussel B, Quivet E, Wortham H, Jaffrezo JL, Baduel C, Voisin D, Besombes JL, Gille G (2009) Comprehensive primary particulate organic characterization of vehicular exhaust emissions in France. Atmos Environ 43: 6190-6198. https://doi.org/10.1016/j.atmosenv.2009.09.001

European Council Directive 2008/50/EC of the European Parliament and of the Council of 21 May 2008 on ambient air quality and cleaner air for Europe.

European Council Directive 2004/107/EC relating to arsenic, cadmium, mercury, nickel and polycyclic aromatic hydrocarbons in ambient air. Official Journal, L023, 26/01/2005, pp. 3-6.

Fine PM, Cass GR, Simoneit BRT (2004) Chemical characterization of fine particle emissions from the wood stove combustion of prevalent United States tree species. Environ Eng Sci 21:705-721. https://doi. org/10.1089/ees.2004.21.705

Fontal M, van Drooge B, López JF, Fernández P, Grimalt JO (2015) Broad spectrum analysis of polar and apolar organic compounds in submicron atmospheric particles. J Chromatogr A 1404:28-38. https://doi.org/10.1016/j.chroma.2015.05.042

Galarneau E (2008) Source specifity and atmospheric processing of airborne PAHs: Implications for source apportionment. Atmos Environ 42:8139-8149. https://doi.org/10.1016/j.atmosenv.2008. 07.025

Garcia MA, Sanchez ML, de Torre B, Perez IA (2007) Characterisation of the mixing height temporal evolution by means of a laser dial system in an urban area - intercomparison results with a model application. Ann Geophys 25:2119-2124. https://doi.org/10.5194/ angeo-25-2119-2007 
Granados-Muñoz MJ, Navas-Guzmán F, Bravo-Aranda JA, GuerreroRascado JL, Lyamani H, Fernández-Gálvez J, Alados-Arboledas L (2012) Automatic determination of the planetary boundary layer height using lidar: one-year analysis over southeastern Spain. J Geophys Res-Atmos 117:D18208. https://doi.org/10.1029/ 2012JD017524

Grosjean D, van Cauwenberghe K, Schmid JP, Kelley PE (1978) Identification of C3-C10 aliphatic dicarboxylic acids in airborne particulate matter. Environ Sci Technol 12:313-317 0013-936X/ 78/0912-0317\$01.00/0

Gonçalves C, Alves C, Fernandes AP, Monteiro C, Tarelho L, Evtyugina M, Pio C (2011) Organic compounds in PM2.5 emitted from fireplace and woodstove combustion of typical Portuguese wood species. Atmos Environ 45:4533-4545. https://doi.org/10.1016/j. atmosenv.2011.05.071

Guzman-Torres D, Eiguren-Fernadez A, Cicero-Fernandez P, MaubertFranco M, Retama-Hernandez A, Ramos-Villegas R, Miquel A (2009) Effects of meteorology on diurnal and nocturnal levels of priority polycyclic aromatic hydrocarbons and elemental and organic carbon in PM10 at a source and receptor area in Mexico city. Atmos Environ 43:2693-2699. https://doi.org/10.1016/j.atmosenv. 2009.03.003

Hallquist M, Wenger JC, Baltensperger U, Rudich Y, Simpson D, Claeys M, Dommen J, Donahue NM, George C, Goldstein AH, Hamilton JF, Herrmann H, Hoffmann T, Iinuma Y, Jang M, Jenkin ME, Jimenez JL, Kiendler-Scharr A, Maenhaut W et al (2009) The formation, properties and impact of secondary organic aerosol: current and emerging issues. Atmos Chem Phys 9:5155-5236. https://doi. org/10.5194/acp-9-5155-2009

Heald CL, Kroll JH, Jimenez JL, Docherty KS, Decarlo PF, Aiken AC, Chen Q, Martin ST, Farmer DK, Artaxo P (2010) A simplified description of the evolution of organic aerosol composition in the atmosphere. Geophys Res Lett 37. https://doi.org/10.1029/ 2010GL042737

Ho KF, Lee SC, Ho SSH, Kawamura K, Tachibana E, Cheng Y, Zhu T (2010) Dicarboxylic acids, ketocarboxylic acids, $\alpha$-dicarbonyls, fatty acids, and benzoic acid in urban aerosols collected during the 2006 Campaign of Air Quality Research in Beijing (CAREBeijing-2006). J Geophys Res 115:D19312. https://doi.org/ 10.1029/2009JD013304

Hoyle, C. R., Boy, M., Donahue, N. M., Fry, J. L., Glasius, M., Guenther, A., Hallar, A. G., Huff Hartz, K., Petters, M. D, Petäjä, T., Rosenoern, T., Sullivan, A. P. (2011). A review of the anthropogenic influence on biogenic secondary organic aerosol, Atmos Chem Phys, 11, 321-343. https://doi.org/10.5194/acp-11-321-2011

Iinuma Y, Brüggemann E, Gnauk T, Müller K, Andreae MO, Helas G, Parmar R, Herrmann H (2007) Source characterization of biomass burning particles: the combustion of selected European conifers, African hardwood, savanna grass, and German and Indonesian peat. J Geophys Res-Atmos 112:D08209. https://doi.org/10.1029/ 2006JD007120

Ion AC, Vermeylen R, Kourtchev I, Cafmeyer J, Chi X, Gelencsér A, Maenhaut W, Claeys M (2005) Polar organic compounds in rural PM2.5 aerosols from K-puszta, Hungary, during a 2003 summer field campaign: sources and diel variations. Atmos Chem Phys 5: 1805-1814. https://doi.org/10.5194/acp-5-1805-2005

Jedynska A, Hoek G, Eeftens M, Cyrys J, Keuken M, Ampe C, Beelen R, Cesaroni G, Forastiere F, Cirach M, de Hoogh K, De Nazelle A, Madsen C, Declercq C, Eriksen KT, Katsouyanni K, Makarem Akhlaghi H, Lanki T, Meliefste K et al (2014) Spatial variations of PAH, hopanes/steranes and EC/OC concentrations within and between European study areas. Atmos Environ 87:239-248. https://doi.org/10.1016/j.atmosenv.2014.01.026

Jimenez JL, Canagaratna MR, Donahue NM, Prevot ASH, Zhang Q, Kroll JH, DeCarlo PF, Allan JD, Coe H, Ng NL, Aiken AC, Docherty KS, Ulbrich IM, Grieshop AP, Robinson AL, Duplissy
J, Smith JD, Wilson KR, Lanz VA et al (2009) Evolution of organic aerosols in the atmosphere. Science 326:1525-1529. https://doi.org/ 10.1126/science. 1180353

Kanakidou M, Seinfeld JH, Pandis SN, Barnes I, Dentener FJ, Facchini MC, Van Dingenen R, Ervens B, Nenes A, Nielsen CJ, Swietlicki E, Putaud JP, Balkanski Y, Fuzzi S, Horth J, Moortgat GK, Winterhalter R, Myhre CEL, Tsigaridis K et al (2005) Organic aerosol and global climate modelling: a review. Atmos Chem Phys 5: 1053-1123. https://doi.org/10.5194/acp-5-1053-2005

Kawamura K, Ikushima K (1993) Seasonal changes in the distribution of dicarboxylic acids in the urban atmosphere. Environ Sci Technol 27: 2227-2235 0013-936X/93/0927-2227\$04.00/0

Kawamura K, Kaplan IR (1987) Motor exhaust emissions as a primary source for dicarboxylic acids in Los Angeles ambient air. Environ Sci Technol 21:105-110

Kawamura K, Yasui O (2005) Diurnal changes in the distribution of dicarboxylic acids, ketocarboxylic acids and dicarbonyls in the urban atmosphere. Atmos Environ 39:1945-1960

Kleindienst TE, Jaoui M, Lewandowski M, Offenberg JH, Docherty KS (2012) The formation of SOA and chemical tracer compounds from the photooxidation of naphthalene and its methyl analogs in the presence and absence of nitrogen oxides. Atmos Chem Phys 12: 8711-8726. https://doi.org/10.5194/acp-12-8711-2012

Krumal K, Mikuska P, Vecera Z (2013) Polycyclic aromatic hydrocarbons and hopanes in PM1 aerosols in urban areas. Atmos Environ 67:27-37. https://doi.org/10.1016/j.atmosenv.2012.10.033

Kubatova A, Vermeylen R, Claeys M, Cafmeyer J, Maenhaut W, Roberts G, Artaxo P (2000) Carbonaceous aerosol characterization in the Amazon basin, Brazil: novel dicarboxylic acids and related compounds. Atmos Environ 34:5037-5051. https://doi.org/10.1016/ S1352-2310(00)00320-4

Laaksonen A, Kulmala M, O’Dowd CD, Joutsensaari J, Vaattovaara P, Mikkonen S, Lehtinen KEJ, Sogacheva L, Dal Maso M, Aalto P, Petäjä T, Sogachev A, Yoon YJ, Lihavainen H, Nilsson D, Facchini MC, Cavalli F, Fuzzi S, Hoffmann T et al (2008) The role of VOC oxidation products in continental new particle formation. Atmos Chem Phys 8:2657-2665. https://doi.org/10.5194/acp-8-2657-2008

Ladji R, Yassaa N, Balducci C, Cecinato A, Meklati BY (2009) Distribution of the solvent-extractable organic compounds in fine (PM1) and coarse (PM1-10) particles in urban, industrial and forest atmospheres of Northern Algeria. Sci Total Environ 408:415-424. https://doi.org/10.1016/j.scitotenv.2009.09.033

Largeron Y, Staquet C (2016) Persistent inversion dynamics and wintertime PM10 air pollution in Alpine valley. Atmos Environ 135:92108. https://doi.org/10.1016/j.atmosenv.2016.03.045

Liu D, Lin T, Hussain Syed J, Cheng Z, Xu Y, Li K, Zhang G, Li J (2017) Concentrations, source identification, and exposure risk assessment of PM2.5-bound parent PAHs and nitro-PAHs in atmosphere of typical Chinese cities. Sci Rep 7:10398. https://doi.org/10.1038/ s41598-017-10623-4

Lyamani H, Fernández-Gálvez J, Pérez-Ramírez D, Valenzuela A, Antón M, Alados I, Titos G, Olmo FJ, Alabos-Arboledas L (2012) Aerosol properties over two urban sites in South Spain during an extended stagnation episode in winter season. Atmos Environ 62:424-432. https://doi.org/10.1016/j.atmosenv.2012.08.050

Maenhout, W., Vermeylen, R., Cleays, M., Vercauteren, J., Matheeusesen, C., Roekens, E. (2012). Assessment of the contribution from wood burning to the PM10 aerosol in Flanders, Belgium. Sci. Total Environ., 437. 226-236. doi.org/10.1016/j.scitotenv.2012. 08.015

Medeiros PM, Simoneit BRT (2007) Analysis of sugars in environmental samples by gas chromatography-mass spectrometry. J Chromatogr A 1141:271-278. https://doi.org/10.1016/j.chroma.2006.12.017

Minguillon MC, Perez N, Marchand N, Bertrand A, Temime-Roussel B, Agrios K, Szidat S, van Drooge B, Sylvestre A, Alastuey A, Reche C, Ripoll A, Marco E, Grimalt JO, Querol X (2016) Secondary 
organic aerosol origin in an urban environment: influence of biogenic and fuel combustion precursors. Faraday Discuss 189:337-359. https://doi.org/10.1039/C5FD00182J

Miyazaki Y, Aggarwal SG, Singh K, Gupta PK, Kawamura K (2009) Dicarboxylic acids and water-soluble organic carbon in aerosols in New Delhi, India, in winter: characteristics and formation processes. J Geophys Res 114:D19206. https://doi.org/10.1029/ 2009JD011790

Moise T, Rudich Y (2002) Reactive uptake of ozone by aerosolassociated unsaturated fatty acids: kinetics, mechanism, and products. J Phys Chem A 106, 6(27):469-6476. https://doi.org/10.1021/ jp025597e

Muller L, Reinnig MC, Naumann KH, Saathoff H, Mentel TF, Donahue NM, Hoffmann T (2012) Formation of 3-methyl-1,2,3butanetricarboxylic acid via gas phase oxidation of pinonic acid - a mass spectrometric study of SOA aging. Atmos Chem Phys 12: 1483-1496. https://doi.org/10.5194/acp-12-1483-2012

Nguyen QT, Christensen MK, Cozzi F, Zare A, Hansen AMK, Kristensen K, Tulinius TE, Madsen HH, Christensen JH, Brandt J, Massling A, Nojgaard JK, Glasius M (2014) Understanding the anthropogenic influence on formation of biogenic secondary organic aerosols in Denmark via analysis of organosulfates and related oxidation products. Atmos Chem Phys 14:8961-8981. https://doi. org/10.5194/acp-14-8961-2014

O’Dowd CD, Aalto P, Hmeri K, Kulmala M, Hoffmann T (2002) Aerosol formation: Atmospheric particles from organic vapours. Nature 416: 497-498. https://doi.org/10.1038/416497a

Paulot F, Wunch D, Crounse JD, Toon GC, Millet DB, Decarlo PF, Vigouroux C, Deutscher NM, Abad GG, Notholt J, Warneke T, Hannigan JW, Warneke C, De Gouw JA, Dunlea EJ, De Mazière M, Griffith DWT, Bernath P, Jimenez JL, Wennberg PO (2011) Importance of secondary sources in the atmospheric budgets of formic and acetic acids. Atmos Chem Phys 11:1989-2013. https:// doi.org/10.5194/acp-11-1989-2011

Perez N, Pey J, Cusack M, Reche C, Querol X, Alastuey A, Viana M (2010) Variability of particle number, black carbon, and PM10, PM 2.5, and PM1 levels and speciation: influence of road traffic emissions on urban air quality. Aerosol Sci Technol 44:487-499. https:// doi.org/10.1080/02786821003758286

Pey J, Pérez N, Querol X, Alastuey A, Cusack M, Reche C (2010) Intense winter atmospheric pollution episodes affecting the Western Mediterranean, Sci. Total Environ 408(8):1951-1959. https://doi. org/10.1016/j.scitotenv.2010.01.052

Pöschl U (2005) Atmospheric Aerosols: Composition, Transformation, Climate and Health Effects. Angew Chem Int Ed 44:7520-7540. https://doi.org/10.1002/anie.200501122

Puxbaum H, Caseiro A, Sánchez-Ochoa A, Kasper-Giebl A, Claeys M, Gelencsér A, Legrand M, Preunkert S, Pio CA (2007) Levoglucosan levels at background sites in Europe for assessing the impact of biomass combustion on the European aerosol background. J Geophys Res-Atmos 112:D23S05. https://doi.org/10.1029/ 2006JD008114

Querol X, Alastuey A, Moreno T, Viana MM, Castillo S, Pey J, Rodríguez S, Artiñano B, Salvador P, Sánchez M, Garcia Dos Santos S, Herce Garraleta MD, Fernandez-Patier R, Moreno-Grau S, Negral L, Minguillón MC, Monfort E, Sanz MJ, Palomo-Marín R et al (2008) Spatial and temporal variations in airborne particulate matter (PM10 and PM2.5) across Spain 1999-2005. Atmos Environ 42:3964-3979. https://doi.org/10.1016/j.atmosenv.2006.10.071

Querol X, Alastuey A, Viana M, Moreno T, Reche C, Minguillon MC, Ripoll A, Pandolfi M, Amato F, Karanasiou A, Perez N, Pey J, Cusack M, Vazquez R, Plana F, Dall'Osto M, de la Rosa J, Sanchez de la Campa A, Fernandez-Camacho R et al (2013, 2013) Variability of carbonaceous aerosols in remote, rural, urban and industrial environments in Spain: implications for air quality policy.
Atmos Chem Phys 13:6185-6206. https://doi.org/10.5194/acp-136185-2013

Reche C, Viana M, Amato F, Alastuey A, Moreno T, Hillamo R, Teinilä K, Saarnio K, Seco R, Peñuelas J, Mohr C, Prévôt A, Querol X (2012) Biomass burning contributions to urban aerosols in a coastal Mediterranean city. Sci Total Environ 427-428:175-190. https://doi. org/10.1016/j.scitotenv.2012.04.012

Robinson AL, Subramanian R, Donahue NM, Bernardo-Bricker A, Rogge WF (2006) Source apportionment of molecular markers and organic aerosol -3 . food cooking emissions. Environ Sci Technol 40(24):7820-7827. https://doi.org/10.1021/es060781p

Rogge WF, Hildemann LM, Mazurek MA, Cass GR, Simoneit BRT (1993a) Sources of fine organic aerosol. 2. Noncatalyst and catalyst-equipped automobiles and heavy-duty diesel trucks. Environ Sci Technol 27:636-651. https://doi.org/10.1021/ es00041a007

Rogge WF, Mazurek MA, Hildemann LM, Cass GR, Simoneit BRT (1993b) Quantification of urban organic aerosols at a molecular level: Identification, abundance and seasonal variation. Atmos Environ Part A General Topics 27:1309-1330. https://doi.org/10. 1016/0960-1686(93)90257-Y

Rolph G, Stein A, Stunder B (2017) Real-time Environmental Applications and Display sYstem: READY. Environ Model Softw 95:210-228. https://doi.org/10.1016/j.envsoft.2017.06.025

Samaké A, Jaffrezo J-L, Favez O, Weber S, Jacob V, Canete T, Albinet A, Charron A, Riffault V, Perdrix E, Waked A, Golly B, Salameh D, Chevrier F, Oliveira DM, Besombes J-L, Martins JMF, Bonnaire N, Conil S et al (2019) Arabitol, mannitol, and glucose as tracers of primary biogenic organic aerosol: the influence of environmental factors on ambient air concentrations and spatial distribution over France. Atmos Chem Phys 19:11013-11030. https://doi.org/10. 5194/acp-19-11013-2019

Satsumabayashi H, Kurita H, Yokouchi Y, Ueda H (1989) Mono- and dicarboxylic acids under long-range transport of air pollution in central Japan. Tellus B 41:219-229. https://doi.org/10.3402/ tellusb.v41i3.15073

Schauer JJ, Rogge WF, Hildemann LM, Mazurek MA, Cass GR, Simoneit BRT (2007) Source apportionment of airborne particulate matter using organic compounds as tracers. Atmos Environ 41:241259. https://doi.org/10.1016/1352-2310(96)00085-4

Schauer JJ, Christensen CG, Kittelson DB, Johnson JP, Watts WF (2008) Impact of ambient temperatures and driving conditions on the chemical composition of particulate matter emissions from non-smoking gasoline-powered motor vehicles. Aersol Sci Technol 42:210-223. https://doi.org/10.1080/02786820801958742

Seco R, Peñuelas J, Filella I, Llusià J, Molowny-Horas R, Schallhart S, Metzger A, Müller M, Hansel A (2011) Contrasting winter and summer VOC mixing ratios at a forest site in the Western Mediterranean Basin: the effect of local biogenic emissions. Atmos Chem Phys 11:13161-13179. https://doi.org/10.5194/acp11-13161-2011

Sicard M, Perez C, Rocadenbosch F, Baldasano J.M, Garcia-Vizcaino D. (2006). Mixed-layer depth determination in the Barcelona coastal area from regular LIDAR measurements: methods, results, and limitation. Bound-Layer Meteorol 119: 135-157. https://doi.org/10. 1007/s10546-005-9005-9

Sicre MA, Marty JC, Saliot A, Aparicio X, Grimalt JO, Albaigés J (1987) Aliphatic and aromatic hydrocarbons in different sized aerosols over the Mediterranean Sea: occurrence and Origin. Atmos Environ 21: $2247-2259$

Simoneit BRT (2002) Biomass burning - a review of organic tracers for smoke from incomplete combustion. Appl Geochem 17:129-162. https://doi.org/10.1016/S0883-2927(01)00061-0

Simoneit BRT, Elias VO, Kobayashi M, Kawamura K, Rushdi AI, Medeiros PM, Rogge WF, Didyk BM (2004) Sugars-Dominant water-soluble organic compounds in soils and characterization as 
tracers in atmospheric particulate matter. Environ Sci Technol 38: 5939-5949. https://doi.org/10.1021/es0403099

Stein, A.F., Draxler, R.R, Rolph, G.D., Stunder, B.J.B., Cohen, M.D., Ngan, F. (2015). NOAA's HYSPLIT atmospheric transport and dispersion modeling system, Bull Amer Meteor Soc, 96, 20592077, https://doi.org/10.1175/BAMS-D-14-00110.1.

Subramanian R, Donahue NM, Bernardo-Bricker A, Rogge WF, Robinson AL (2006) Contributions of motor vehicle emissions to organic carbon and fine particle mass in Pittsburg, Pennsylvania: effects of varying source profiles and seasonal trends in ambient marker concentrations. Atmos Environ 40:8002-8019. https://doi. org/10.1016/j.atmosenv.2006.06.055

Surratt JD, Chan AWH, Eddingsaas NC, Chan M, Loza CL, Kwan AJ, Hersey SP, Flagan RC, Wennberg PO, Seinfeld JH (2010) Reactive intermediates revealed in secondary organic aerosol formation from isoprene. Proc Natl Acad Sci U S A 107:6640-6645. https://doi.org/ 10.1073/pnas.0911114107

Szmigielski R, Surratt JD, Gómez-González Y, van der Veken P, Kourtchev I, Vermeylen R, Blockhuys F, Jaoui M, Kleindienst TE, Lewandowski M, Offenberg JH, Edney EO, Seinfeld JH, Maenhaut W, Claeys M (2007) 3-methyl-1,2,3-butanetricarboxylic acid: an atmospheric tracer for terpene secondary organic aerosol. Geophys Res Lett 34:L24811. https://doi.org/10.1029/ 2007GL031338

Tauler R (1995) Multivariate curve resolution applied to second order data. Chemometr Intell Lab 30:133-146. https://doi.org/10.1016/ 0169-7439(95)00047-X

Tauler R., Paatero P., Hopke P.K., Henry R.C., Spiegelman C., Park E.S., Poirot R.L. (2006) State of the art in methods and software for the identification, resolution and apportionment of contamination sources. 3rd International Congress on Environmental Modelling and Software - Burlington, Vermont, USA - July 2006. http:// www.iemss.org/iemss2006/papers/w9/pp.pdf

Tauler R, Viana M, Querol X, Alastuey A, Flight RM, Wentzell PD, Hopke PK (2009) Comparison of the results obtained by four receptor modelling methods in aerosol source apportionment studies. Atmos.Environ. 43:3989-3997. https://doi.org/10.1016/j. atmosenv.2009.05.018

Timonen H, Saarikoski S, Tolonen-Kivimäki O, Aurela M, Saarnio K, Petäjä T, Aalto PP, Kulmala M, Pakkanen T, Hillamo R (2008) Size distributions, sources and source areas of water-soluble organic carbon in urban background air. Atmos Chem Phys 8:5635-5647. https://doi.org/10.5194/acp-8-5635-2008

Titos G, del Águila A, Cazorla A, Lyamani H, Casquero-Vera JA, Colombi C, Cuccia E, Gianelle V, Močnik G, Alastuey A, Olmo FJ, Alados-Arboledas L (2017) Spatial and temporal variability of carbonaceous aerosols: assessing the impact of biomass burning in the urban environment. Sci Total Environ 578:613-625. https://doi. org/10.1016/j.scitotenv.2016.11.007

Triantafyllou A (2001) PM10 pollution episodes as a function of synoptic climatology in a mountainous industrial area. Environ Pollut 112: 491-500. https://doi.org/10.1016/S0269-7491(00)00131-7

van Drooge BL, Pérez-Ballesta P (2009) Seasonal and daily source apportionment of polycyclic aromatic hydrocarbon concentrations in $\mathrm{PM}_{10}$ in a semirural European area. Environ Sci Technol 43:7310 7316. https://doi.org/10.1021/es901381a van Drooge BL, Cusack M, Reche C, Mohr C, Alastuey A, Querol X, Prevot A, Day DA, Jimenez JL, Grimalt JO (2012) Molecular marker characterization of the organic composition of submicron aerosols from Mediterranean urban and rural environments under contrasting meteorological conditions. Atmos Environ 61:482-489. https://doi. org/10.1016/j.atmosenv.2012.07.039

van Drooge BL, Fontal M, Bravo N, Fernández P, Fernández MA, Muñoz-Arnanz J, Jiménez B, Grimalt JO (2014) Seasonal and spatial variation of organic tracers for biomass burning in PM1 aerosols from highly insolated urban areas. Environ Sci Pol 21:1166111670. https://doi.org/10.1007/s11356-014-2545-0

van Drooge BL, Grimalt JO (2015) Particle sized-resolved source apportionment of primary and secondary organic tracer compounds at urban and rural locations in Spain. Atmos Chem Phys 7735-7752: 7735-7752. https://doi.org/10.5194/acp-15-7735-2015

van Drooge BL, Fontal M, Fernández P, Fernández MA, Muñoz-Arnanz J, Jiménez B, Grimalt JO (2018) Organic molecular tracers in atmospheric $\mathrm{PM}_{1}$ at urban intensive traffic and background sites in two high-insolation European cities. Atmos Environ 188:71-81. https:// doi.org/10.1016/j.atmosenv.2018.06.024

Vardoulakis S, Kassomenos P (2008) Sources and factors affecting PM10 levels in two European cities: implications for local air quality management. Atmos Environ 3949-3963:3949-3963. https://doi.org/10. 1016/j.atmosenv.2006.12.021

Vecchi R, Marcazzan G, Valli G (2007) A study on nighttime-daytime PM10 concentration and elemental composition in relation to atmospheric dispersion in the urban area of Milan (Italy). Atmos Environ 41:2136-2144. https://doi.org/10.1016/j.atmosenv.2006.10.069

Wang G, Kawamura K, Xie M, Hu S, Gao S, Cao J, An Z, Wang Z (2009) Size-distributions of $n$-alkanes, PAHs and hopanes and their sources in the urban, mountain and marine atmospheres over East Asia. Atmos Chem Phys 9:8869-8882. https://doi.org/10.5194/acp-98869-2009

Yang X, Jiang L, Zhao W, Xiong W, Zhao W, Yan X (2018) Comparison of ground-based PM2.5 and PM10 concentrations in China, India, and the US. Int J Environ Res Public Health 15:1382. https://doi.org/ 10.3390/ijerph15071382

Yao XH, Chan CK, Fang M, Cadle S, Chan T, Mulawa P, He KB, Ye BM (2002) The water-soluble ionic composition of PM2.5 in Shanghai and Beijing, China. Atmos Environ 36:4223-4234. https://doi.org/10.1016/S1352-2310(02)00342-4

Yue Z, Fraser MP (2004) Polar organic compounds measured in fine particulate matter during TexAQS 2000. Atmos Environ 38:32533261. https://doi.org/10.1016/j.atmosenv.2004.03.014

Zhang Q, Jimenez JL, Canagaratna MR, Allan JD, Coe H, Ulbrich I, Alfarra MR, Takami A, Middlebrook AM, Sun YL, Dzepina K, Dunlea E, Docherty K, DeCarlo PF, Salcedo D, Onasch T, Jayne JT, Miyoshi T, Shimono A et al (2007) Ubiquity and dominance of oxygenated species in organic aerosols in anthropogenicallyinfluenced northern hemisphere mid-latitudes. Geophys Res Lett 34:L13801. https://doi.org/10.1029/2007GL029979

Publisher's note Springer Nature remains neutral with regard to jurisdictional claims in published maps and institutional affiliations. 